\title{
Use of Animal Models for Anti-HIV Drug Development
}

\author{
Zandrea Ambrose \\ University of Pittsburgh, \\ USA
}

\section{Introduction}

Animal models serve as important tools for preclinical testing of therapeutic regimens against human immunodeficiency virus (HIV-1), the primary etiologic agent that causes acquired immunodeficiency syndrome (AIDS). Infection and treatment of patients often cannot be controlled in clinical studies. In addition, performing certain procedures and sampling cannot be routinely performed in humans with ease and may be unethical. There are many different primate and murine models of HIV/AIDS, each with their advantages and disadvantages. Some models are appropriate in certain contexts but not others. Knowing how the different models work and their limitations will help guide the researcher to select the appropriate model to answer a specific question. Information gained from the use of preclinical testing of antiretroviral therapies will help identify and improve preventive, therapeutic, and eradication strategies against HIV/AIDS in humans.

\section{HIV-1 infection of nonhuman primates or humanized mice: Which is the better model to use?}

An animal model for human disease should mimic the infection of humans as closely as possible. The disease course in the model should be similar to or more accelerated than in humans. In the case of HIV-1, an animal model that progresses to AIDS over the period of many years will cost time and money in preclinical studies. The use of animals instead of humans usually means certain procedures can be performed more easily and/or ethically. For example, removing vital organs to study pathogenesis, drug penetration, immunity, or virology cannot be performed in humans but can be done after necropsy of an animal. Moreover, unlike in humans, the exact virus, timing of infection, and timing of treatment can be controlled in a model.

HIV-1 does not efficiently replicate in most animals, including nonhuman primates. This is due to differences in host cell factors present in different species that are required for infection or due to innate immunity that appears to have evolved in mammals to ward off infections. Thus, either modification to HIV-1 or to the animal must be made for significant viral replication to occur. This is important for assessing the efficacy of experimental interventions for inhibiting the virus rather than spontaneous control by the host immune system. 


\subsection{Nonhuman primate models}

Nonhuman primates are genetically and anatomically most similar to humans and would be the obvious choice for an animal model to study HIV-1. While HIV-1 is believed to have arisen from cross-species transmission of simian immunodeficiency virus (SIV) strains from chimpanzees and gorillas to humans (Keele et al., 2006; Van Heuverswyn et al., 2006), these animals are not routinely used for HIV research. These great apes are both endangered and very large. And although HIV-1 has been used in the past to infect chimpanzees in captivity, it does not cause significant disease for more than a decade (Novembre et al., 1997). Thus, this is an impractical model for testing treatments and vaccines against the virus.

Macaques, a genus of Old World monkeys, are routinely bred at primate centers and have been extensively investigated as HIV models. HIV-1 inoculation of macaques does not lead to productive infection, mainly due to restriction by simian innate immune factors, such as APOBEC3G and TRIM5 $\alpha$, that target HIV-1 (Mariani et al., 2003; Stremlau et al., 2004). SIV is a primate lentivirus that is similar to HIV-1 and highly homologous to HIV type 2 (HIV2), which was isolated from rhesus macaques at a primate facility (Daniel et al., 1985; Kanki et al., 1985). SIV infection of macaques is believed to have been another cross-species transmission during captivity from infected African primates (Hirsch et al., 1989), leading to pathogenesis similar to AIDS but in a more accelerated time frame as compared to HIV-1 infection of humans. In addition, adaptive immune responses against SIV in macaques are similar to anti-HIV-1 responses seen in humans (Sato and Johnson, 2007; Valentine and Watkins, 2008). The most widely used species of macaques for HIV/AIDS models are rhesus (Macaca mulatta), cynomolgus (M. fasicularis), and pigtailed (M. nemestrina).

While SIV shares high structural and sequence identity to HIV-1, the differences are significant enough to limit the design of both vaccines and therapy against the human virus. Therefore, HIV-1 sequences have been added into the SIV genome to make chimeric viruses, called SHIVs, which can still replicate well within macaques (Fig. 1). The first examples of SHIVs were SIV strains that encoded HIV-1 envelope in place of SIV envelope, such that vaccines or drugs could target this entry protein (Li et al., 1992; Luciw et al., 1995; Reimann et al., 1996; Shibata et al., 1991). More recently, the reverse transcriptase (RT) coding region of SIVs have been replaced with that of HIV-1 to produce RT-SHIV that can be targeted by RT inhibitors (Ambrose et al., 2004; Uberla et al., 1995). Both types of SHIVs have been shown to infect macaques after mucosal exposure, simulating sexual transmission (Lu et al., 1996; Turville et al., 2008). Simian-tropic HIV-1 (stHIV-1) viruses have been made that contain minimal SIV sequences (capsid and Vif coding regions) to circumvent restriction from APOBEC3G and TRIM5 $\alpha$, but they suffered significant decreases in replication in the host compared to SIV or the previously described SHIVs, likely due to differences in the accessory proteins of HIV-1 as compared to SIV (Hatziioannou et al., 2009; Igarashi et al., 2007).

Baboons and other species of Old World monkeys have also been used as nonhuman primate models for studying HIV infection and AIDS. Baboons could be productively infected with HIV-2 but showed little pathogenesis (Barnett et al., 1994). African green monkeys and sooty mangabeys are naturally infected with SIV but do not experience disease despite very high levels of viremia. These animals are studied for their differences to Asian macaques to understand chronic, pathogenic SIV/HIV infection (Paiardini et al., 2009). 


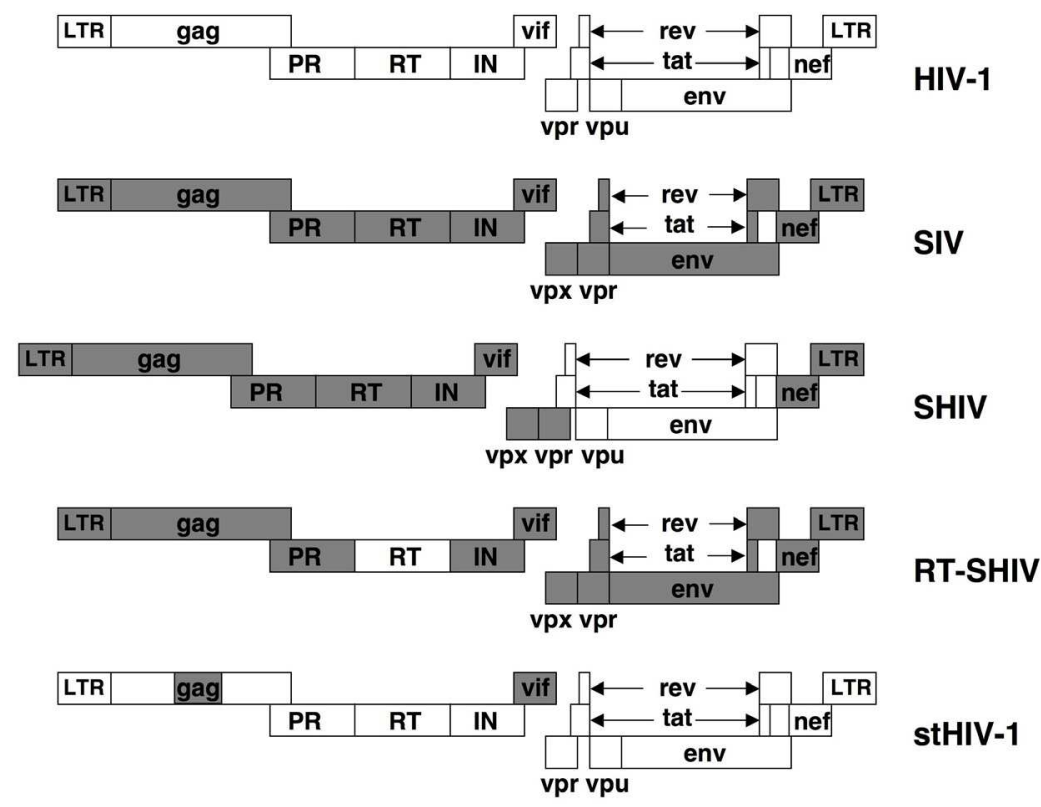

Fig. 1. Diagram of the genomes of HIV-1, SIV, and chimeric viruses used in macaques. White color denotes HIV-1 sequences, while gray shading denotes SIV sequences.

\subsection{Humanized mouse models}

The strengths of murine models for biomedical research are the small size of mice and their relatively low cost, making it feasible to have increased numbers of animals in experiments for greater statistical power. However, HIV-1 encounters multiple barriers in the infection of mouse cells, beginning with the inability of the virus to use the murine CD4 receptor and coreceptors. To overcome these issues, scientists reconstituted a partial human immune system in severe combined immunodeficient (SCID) mice lacking lymphocytes by engrafting them with human peripheral blood lymphocytes or human fetal thymus and liver (Mosier et al., 1988; Namikawa et al., 1990). However, while peripheral T cell subsets could be reconstituted temporarily in these SCID-hu mice, they were not detected to a great extent in tissues. In addition, other human immune cells did not develop and only transient HIV-1 replication could be detected in vivo.

Due to the limitations of SCID-hu mice, new advances in humanized murine models have been made to better reconstitute a human immune system and to lead to sustained HIV-1 replication. First, the addition of the SCID mutation into the nonobese diabetic strain (NOD/SCID), which lacks the IL-2 receptor $\gamma$-chain, resulted in mice without T, B, and NK cells. With the implantation of human $\mathrm{CD}^{+} 4^{+}$hematopoietic stem cells into these mice, they developed human lymphocytes and dendritic cells in the blood and in multiple lymphoid tissues. Thus, HIV-1 infection could be sustained at high levels for more than 40 days (Watanabe et al., 2007). Similarly, transplantation of human fetal bone marrow (containing CD34+ cells), liver, and thymus (BLT) into NOD/SCID mice could also generate functional human T, B, and dendritic cells in both the periphery and tissues. These animals could 
stably maintain HIV-1 replication after intrarectal or intravaginal challenge (Denton et al., 2008; Sun et al., 2007). However, NOD/SCID mice develop thymic lymphomas, resulting in a limited lifespan (Shultz et al., 1995).

Another humanized mouse model utilizes Rag2-/ $\gamma \mathrm{C}^{-/-}$double knockout mice, which also lack T, B, and NK cells. These mice can also be reconstituted with CD34 ${ }^{+}$hematopoietic stem cells, leading to development of human T, B, and dendritic cells in the blood and different lymphoid tissues (Traggiai et al., 2004). The animals could be infected with HIV-1 and had detectable viremia for more than 27 weeks (Baenziger et al., 2006). Like the BLT model, Rag2 $/-\gamma \mathrm{C}^{-/-}$mice also had $\mathrm{CD}^{+}$target cells in mucosal tissues and could be infected intrarectally or intravaginally (Berges et al., 2008).

\begin{tabular}{|c|c|c|c|}
\hline \multicolumn{2}{|c|}{ Macaques } & \multicolumn{2}{|c|}{ Humanized CD34 ${ }^{+}$reconstituted mice } \\
\hline Advantages & Disadvantages & Advantages & Disadvantages \\
\hline $\begin{array}{l}\text { Similar viral } \\
\text { pathogenesis to } \\
\text { humans }\end{array}$ & $\begin{array}{l}\text { Genetically different } \\
\text { than humans }\end{array}$ & $\begin{array}{l}\text { Target cells are } \\
\text { human }\end{array}$ & $\begin{array}{l}\text { Lack of macro- } \\
\left.\text { phages (Rag2/ } \gamma \mathrm{C}^{-/-}\right) \\
\text {and robust anti- } \\
\text { retroviral immunity }\end{array}$ \\
\hline $\begin{array}{l}\text { Similar antiviral } \\
\text { immune responses to } \\
\text { humans }\end{array}$ & Requires SIV or SHIV & $\begin{array}{l}\text { Can use different } \\
\text { HIV-1 strains }\end{array}$ & $\begin{array}{l}\text { Small tissue/blood } \\
\text { samples }\end{array}$ \\
\hline $\begin{array}{l}\text { Long-term viral } \\
\text { persistence during } \\
\text { suppressive anti- } \\
\text { retroviral therapy }\end{array}$ & $\begin{array}{l}\text { Expensive and } \\
\text { requires trained } \\
\text { veterinary staff }\end{array}$ & $\begin{array}{l}\text { Can create genetic- } \\
\text { ally identical animals } \\
\text { with cells from same } \\
\text { donor }\end{array}$ & $\begin{array}{l}\text { Requires access to } \\
\text { donor tissues and } \\
\text { ability to perform } \\
\text { transplants }\end{array}$ \\
\hline $\begin{array}{l}\text { Access to large } \\
\text { tissue/blood samples }\end{array}$ & $\begin{array}{l}\text { Large size requiring } \\
\text { more drugs }\end{array}$ & Less overall cost & $\begin{array}{l}\text { Anatomically diff- } \\
\text { erent than humans }\end{array}$ \\
\hline Longer lifespan & & $\begin{array}{l}\text { Small size allows the } \\
\text { use of less drugs }\end{array}$ & $\begin{array}{l}\text { Limited lifespan, } \\
\text { especially BLT }\end{array}$ \\
\hline
\end{tabular}

Table 1. Advantages and disadvantages to simian and murine models of HIV/AIDS

\subsection{What virus should be used with which model?}

With a wide array of simian and murine models of HIV/AIDS, it is difficult to know which one to use to answer a scientific question. Each model has its advantages and disadvantages (Table 1). Depending on the question, one has to weigh the pros and cons that may affect the results in deciding which model and which virus to employ. For example, macaques are more anatomically similar to humans and studying drug penetration into tissues or inhibition of virus in tissues, such as microbicides, may be more relevant in the monkey model. However, at this time HIV-1 replication is very limited in simians, necessitating the use of SIV or SHIVs. Therefore, drugs targeting viral proteins or virus-host cell protein interactions may be limited with these viruses and may require the use of HIV-1 in mice. Although mice are smaller and cheaper than monkeys, humanized murine models require significant expertise and human donors for tissue implantation and stem cell reconstitution that may not be more cost-effective for the investigator. The rest of the chapter will discuss the use of both simian and murine models for preclinical studies of anti-HIV therapies. 


\section{Therapy for HIV-1 prevention in animal models}

As there is no cure for HIV-1 yet, efforts have been made to develop and evaluate compounds that would prevent HIV-1 infection prior to or immediately after exposure to the virus. These differ from vaccines in that they are not designed to elicit antiviral immunity in advance of exposure, but rather would inhibit the virus before, during, or just after exposure to HIV-1 to avoid systemic infection. Pre-exposure prophylaxis would be initiated in high-risk individuals likely to be exposed to HIV-1, whereas post-exposure prophylaxis would be used in individuals who were believed to be recently exposed to the virus. Animal models have been used rather extensively over the past decade in this area of research with generally positive results. Unlike in clinical trials, the timing and adherence of treatment and the timing of virus challenge can be controlled in the model.

\subsection{Pre-exposure prophylaxis}

The majority of prevention therapy studies have focused on pre-exposure prophylaxis, or microbicides, against mucosal transmission of virus. This is particularly relevant in areas of the world where people, especially women, often are unable to control their partners' use of condoms during sexual intercourse. Thus, a compound that can be applied mucosally or taken orally could inhibit HIV-1 infection either by targeting the virus or targeting viral interaction with host cell factors necessary for viral replication.

\subsubsection{Toxicity of mucosal drug application}

Generally, compounds that inhibit HIV-1 are discovered and characterized in vitro. Before going to clinical trials for efficacy testing, tolerability and toxicity studies in animals or people are often performed. In the case of topically applied microbicides, this entails determining whether a drug causes disruption of the mucosal epithelial layer that forms an intact barrier against incoming pathogens. The need for toxicity testing was made dramatically clear in the case of nonoxynol-9 (N-9), which was halted in clinical trials as a potential anti-HIV topical microbicide due to toxic effects that made users more susceptible to HIV-1 infection. N-9, a nonionic detergent present in some contraceptive gels, was shown long ago to inhibit viral replication in vitro (Hicks et al., 1985). Several clinical studies of N-9 use in women during vaginal sexual intercourse suggested that it slightly increased the risk for HIV-1 seroconversion (Wilkinson et al., 2002). There were discrepancies on whether or not N-9 caused toxicity in the female genital tract, which may have been due to poor adherence and inappropriate application of the product. A careful study in the pigtailed macaque model showed that N-9 caused genital tissue damage (Patton et al., 1999).

The female genital tract consists of stratified squamous epithelial cells (vagina and ectocervix) and simple columnar epithelium (endocervix), while the GI tract consists only of a single layer of columnar epithelial cells. Trials of N-9 for rectal use showed that histological abnormalities occurred in almost $90 \%$ of the subjects (Tabet et al., 1999) and caused rapid exfoliation of the rectal epithelium (Phillips et al., 2000). Similar results were also observed in pigtailed macaques (Patton et al., 2002), suggesting that safety testing is necessary for microbicides prior to initiating clinical studies to prevent enhanced HIV-1 transmission.

Inflammation and toxicity markers and their correlation, or lack thereof, with complete protection from transmission are still incompletely defined. Administration of a foreign 
compound is likely to induce innate immune responses. This is also the initial response of the body in countering HIV-1 immediately following exposure. Maintaining normal, intact tissue and normal microflora at mucosal sites during use of a topical microbicide will continue to be a challenge. And the use of oral drugs that can penetrate tissues also will need to be evaluated for safety and lack of mucosal toxicity.

\subsubsection{Therapeutic prevention studies}

Many compounds have been tested as pre-exposure prophylaxis in animal models prior to intravaginal, intrarectal, or oral exposure of virus. Such preventive drugs can be nonspecific to HIV-1 or specific antiretroviral compounds. Intravaginal or intrarectal transmission of HIV-1 occurs during sexual contact, while oral transmission may contribute to infection of infants during vaginal delivery. While both macaque and humanized mouse models have been useful for mucosal viral transmission, HIV-1 can only be used to infect humanized mice. Macaques can be infected effectively with chimeric SHIV viruses containing HIV-1 envelope or RT. And the anatomy of nonhuman primates, including the gastrointestinal and genital tracts, is more similar to that of humans.

The majority of such pre-exposure prophylaxis studies have been performed with various levels of success in female macaques for the prevention of vaginal transmission. Compounds tested in macaque models have aimed to interfere with nonspecific viral attachment (Ambrose et al., 2008; Boadi et al., 2005; Kenney et al., 2011; Kim et al., 2006; Lagenaur et al., 2011; Li et al., 2009; Manson et al., 2000; Tevi-Benissan et al., 2000; Tsai et al., 2004; Wyand et al., 1999), specific interactions of envelope with receptor/co-receptors (KishCatalone et al., 2007; Lederman et al., 2004; Mascola et al., 2000; Parren et al., 2001; Veazey et al., 2008; Veazey et al., 2010; Veazey et al., 2003a; Veazey et al., 2005a; Veazey et al., 2009; Veazey et al., 2003b; Veazey et al., 2005b), and reverse transcription (Kenney et al., 2011; Parikh et al., 2009; Stolte-Leeb et al., 2011; Turville et al., 2008). Another study investigated hormone treatment, which leads to thickening of the vaginal epithelium, to prevent vaginal transmission of SIV in macaques (Smith et al., 2000b). More recently, the humanized mouse model has been used to prevent intravaginal transmission, using drugs targeting RT (Denton et al., 2008; Denton et al., 2011), integrase (Neff et al., 2011a), the CCR5 co-receptor (Neff et al., 2011a; Neff et al., 2010), and viral protein expression (Wheeler et al., 2011).

Fewer studies have evaluated compounds that prevent intrarectal or oral transmission of HIV-1 or SHIVs. The FDA-approved RT inhibitor tenofovir was successful in preventing intrarectal transmission of SIV in macaques (Cranage et al., 2008) and of HIV-1 in humanized mice (Denton et al., 2010). Also, a novel RT inhibitor (Singer et al., 2011) and a nonspecific envelope attachment inhibitor (Tsai et al., 2003) were used to prevent intrarectal transmission of SHIVs in macaques. For prevention of oral viral transmission, only macaque models have been used. First, neutralizing antibodies were shown to be protective in neonates (Baba et al., 2000). More recently, subcutanously administered tenofovir was found to be somewhat protective against oral SIV challenge (Van Rompay et al., 2006; Van Rompay et al., 2001) while an oral tenofovir solution was ineffective (Van Rompay et al., 2006; Van Rompay et al., 2002b).

While most of these studies have focused on topical gels and novel compounds, oral FDAapproved antiretroviral compounds have been investigated recently as pre-exposure 
prophylaxis. Tenofovir prevents HIV-1 replication, it is already approved for use in humans in the oral formulation, and high drug concentrations can be achieved in the male and female genital tracts (Kwara et al., 2008; Vourvahis et al., 2008). The use of a gel may not provide complete coverage of the mucosal surface, possibly leading to breakthrough infections. The CAPRISA 004 clinical trial recently showed a 39\% overall reduction in HIV-1 incidence in women using a vaginal tenofovir gel (Abdool Karim et al., 2010). The iPrEx and TDF2 trials showed that oral tenofovir in combination with another RT inhibitor, emtracitabine (FTC), reduced transmission in men who have sex with men (Grant et al., 2010) or in heterosexual men and women (Roehr, 2011) by $44 \%$ and $63 \%$, respectively. It is unclear whether the greater efficacy in the latter studies as compared to the CAPRISA 004 study was due to oral administration of drug or use of two drugs instead of tenofovir alone. In macaques, intermittent dosing ( 2 hours before and 24 hours after challenge) of tenofovir alone or with FTC was equally as effective as daily dosing during weekly repeated low-dose rectal challenges (Garcia-Lerma et al., 2008). Less frequent doses would reduce cost to the user and would not require strict daily adherence. However, breakthrough infections in 2 of 6 animals resulted in drug resistant viruses, which could potentially compromise future therapy.

Interestingly, with the exception of tenofovir or tenofovir/FTC, no other microbicides have been successful in the clinic. It remains to be seen whether or not this is due to a specific property of tenofovir or RT inhibitors in general. Tenofovir acts specifically on viral reverse transcription, whereas most other microbicides tested clinically were nonspecific entry inhibitors. Also, tenofovir is the only drug that has been tested with repeated low-dose SIV oral, intravaginal, and intrarectal challenges in macaques (Garcia-Lerma et al., 2008; Parikh et al., 2009; Van Rompay et al., 2006). A nonspecific virus inactivating compound was tested in repeated high-dose intravaginal challenges 10-47 weeks apart, in which $90 \%$ of the animals were protected after the initial challenge (Ambrose et al., 2008). However, nearly all the animals became infected after the second challenge. It is unclear if noninfectious virus at the site of transmission elicits a detrimental immune response, inflammation, and/or an increase in target cells that can cause a subject to become more sensitized to infection.

Until recently, mucosal challenge of SIV or SHIV required high doses of virus to ensure that all or most of the control animals become infected. More and more investigators are using repeated low-dose challenges in animal studies to recapitulate more realistic levels of virus detected in semen of untreated HIV+ men. Semen viral RNA levels are often similar to or lower than in the blood (Gupta et al., 1997; Liuzzi et al., 1996), but are significantly lower than those of laboratory stocks used in high-dose challenges (Marthas et al., 2001). Also, high-risk individuals may be exposed multiple times prior to becoming infected. A direct comparison of a high-dose challenge and repeated low-dose rectal challenges in a small study on oral tenofovir pre-exposure prophylaxis showed that the low-dose model was actually somewhat more stringent (Subbarao et al., 2007). The disadvantage of the low-dose model is that multiple challenges are required to infect untreated control monkeys, and this number varies significantly among animals. This can affect statistics and often leads to longer experiments, which can increase study costs.

\subsection{Post-exposure prophylaxis}

Most post-exposure prophylaxis research has focused on entry and reverse transcription inhibitors that target the earliest steps of HIV-1 replication. Tenofovir was the first 
successful drug used for post-exposure treatment in the macaque model against intravenous challenge of SIV (Tsai et al., 1995). Animals did not become infected when daily tenofovir treatment was initiated 4 or 24 hours post-challenge, continuing for 4 weeks. A similar study with AZT did not show protection 3 hours after intravenous SIV inoculation (Fazely et al., 1991). Later, vaginal transmission was largely prevented in macaques after tenofovir treatment began 12 or 36 hours post-challenge but not after 72 hours (Otten et al., 2000).

The other post-exposure prophylaxis method used in the macaque model has been passive transfer of neutralizing antibodies targeting HIV-1 envelope. Antibody transfer into macaques 6 hours post-infection with SHIV showed 75\% protection, which declined to $50 \%$ after 24 hours (Nishimura et al., 2003). Multiple monoclonal antibodies were more successful than an individual antibody. Complete protection was also seen after antibody infusion 1 hour after oral SHIV challenge of neonates, which decreased after 12 or 24 hours (Ferrantelli et al., 2004).

While these post-exposure prophylaxis studies showed promise, highly pathogenic viruses may be more difficult to control. One study showed that a combination of neutralizing antibodies given to neonates at 1 hour and 8 days post-challenge led to $100 \%$ protection in animals infected with a SHIV, but did not protect animals from a more pathogenic virus (Hofmann-Lehmann et al., 2001). This same highly pathogenic virus also failed to be controlled by triple therapy of AZT, 3TC, and the protease inhibitor indinavir when initiated 4 hours after intravenous infection and continued for 14-28 days (Bourry et al., 2009; Le Grand et al., 2000). These studies noted that although most of the animals became infected, plasma viremia was reduced compared to the control animals, suggesting a partial protective effect of the treatment regimens.

\subsection{Mother-to-child transmission prevention}

Mother-to-child transmission (MTCT) of HIV-1 occurs via three mechanisms: in utero via virus transfer across the placenta, intrapartum presumably by oral inoculation of the infected mother's blood, and breastfeeding. An early clinical trial showed that AZT therapy of HIV-infected women during pregnancy and of infants in the first 6 weeks after birth led to a $67.5 \%$ reduction in MTCT (Connor et al., 1994).

In resource-rich nations, combination therapy is now the standard of care for pregnant women. However, the cost of multiple drugs and/or multiple doses of drugs poses a challenge in resource-limited countries. Thus, studies were conducted in which single doses of nevirapine were administered to women during labor (and sometimes to the infant) to prevent MTCT. Nevirapine, a non-nucleoside RT inhibitor, has less toxicity than AZT and has a long half-life (Musoke et al., 1999). Single-dose nevirapine treatment effectively reduced HIV-1 MTCT to a similar degree as multiple doses of AZT (Guay et al., 1999). Unfortunately, it was revealed that single-dose nevirapine caused the development of drugresistant virus in the mothers and in infants that subsequently became infected (Eshleman et al., 2001), which could be present at low frequencies for long periods of time (Flys et al., 2005; Palmer et al., 2006). Such drug resistance compromised subsequent treatment in the mothers (Jourdain et al., 2004).

Few studies on MTCT have been performed in animal models. One study using a pregnant macaque model of MTCT showed that short-term combination therapy could successfully 
prevent in utero transmission of HIV-2 to the fetus/infant (Ho et al., 2000). SIV transmission in nonhuman primates via breastfeeding has been demonstrated and used to study tenofovir pharmacokinetics in breast milk (Van Rompay et al., 2005). However, this model has not be used in any therapeutic prevention studies. Oral inoculation macaque models have been used to study pre-exposure and post-exposure prophylaxis, as discussed above.

It appears that the first few hours after virus exposure is critical for using therapy to stop infection. This is important to minimize the spread of virus to new target cells. While most research has focused on a single inhibitor or class of inhibitors, it remains to be seen if drug combinations will afford more time to an exposed individual to prevent fulminant infection. Treatment of adults and infants, even when initiated immediately after exposure, may be ineffective if they have been exposed to drug-resistant or highly pathogenic viruses. This could be alleviated with combination therapy. Also, post-exposure treatment has generally been administered daily for 4 weeks. To save money and to avoid prolonged side effects from the drugs, can the duration of therapy be shortened and remain effective? Finally, will breakthrough infections result in selection of drug-resistant viruses, which could lead to virologic failure during subsequent antiretroviral treatment?

\section{Animal models for new suppressive antiretrovirals, combinations, and deliveries}

Animal models for antiretroviral research can be used to test novel compounds for their toxic properties, pharmacokinetics and bioavailability, and antiretroviral efficacy.

\subsection{Toxicity, pharmacokinetics, tissue distribution}

While it is impossible to document or list all antiretroviral pharmacokinetics and toxicity research in animals here, a few examples of early and new studies should be noted. Nucleoside analogs that inhibit reverse transcription, such as ddC (Kelley et al., 1987) and d4T (Keller et al., 1995), were tested in mice and monkeys for toxicity and pharmacokinetics. The short-term and long-term effects of tenofovir in newborn/infant macaques showed bone and kidney toxicities (Van Rompay et al., 2004). Also, non-nucleoside RT inhibitors, such as efavirenz, were tested in animals for pharmacokinetics (Balani et al., 1999). Investigators also developed drugs to the other HIV-1 enzymes: protease and integrase. While many of the protease inhibitors had poor efficacy against SIV, their pharmacokinetics could be assessed in animals, such as that of nelfinavir (Kaldor et al., 1997). Many integrase inhibitors were screened by Merck, leading to testing of many potential new compounds for good bioavailability in nonhuman primates and mice (Gardelli et al., 2007; Pace et al., 2007). Even HIV-1 entry inhibitors, such as SCH-D, which would later be named vicriviroc, were tested in mice and monkeys for general pharmacokinetics (Tagat et al., 2004). Also, maraviroc was studied for intrapartum pharmacokinetics and dynamics in pregnant macaques as a potential method to prevent MTCT (Winters et al., 2010).

\subsection{Efficacy in viral inhibition}

The virus and model used to test antiretroviral drug efficacy are dependent on the drug target. For example, due to sequence differences in the Gag protein, the maturation inhibitor bevirimat does not inhibit SIV (Zhou et al., 2004). Therefore, proof of concept in vivo studies 
were performed in a humanized mouse model to show drug inhibition against HIV-1 (Stoddart et al., 2007). Similarly, testing of a CCR5 inhibitor like maraviroc is best used with HIV-1 envelope. Therefore, nonhuman primate studies were performed with SHIV virus containing a CCR5-tropic envelope (Veazey et al., 2003a).

Many novel antiretroviral small molecule inhibitors have been characterized for efficacy against HIV, SIV, or SHIV in animal models, many leading to FDA approval or to more improved versions of the compounds (reviewed in Ambrose and KewalRamani, 2008; Van Rompay, 2010). For example, PMEA, a drug related to tenofovir, was found to inhibit SIV infection effectively in macaques (Balzarini et al., 1991). Unfortunately, PMEA was very toxic in vivo, which lead to the development of the related and less-toxic compound tenofovir (previously called PMPA), which has been studied extensively in monkeys for viral inhibition (Balzarini et al., 1991; Lifson et al., 2003; Smith et al., 2000a; Tsai et al., 1998). Another RT inhibitor, stavudine, was tested for antiretroviral properties in HIV-2-infected macaques (Watson et al., 1997). And after many years of screening compounds in vitro, a precursor to the first FDA-approved integrase inhibitor, raltegravir, was shown to be effective in viral inhibition in the macaque model (Hazuda et al., 2004).

While many exciting novel antiretroviral inhibitors are currently under investigation in in vitro models, general efficacy testing is not always performed in an animal model prior to clinical studies. This is due to the high costs associated with these experiments, particularly in macaques and humanized mice. The major advantage of an animal model is the ability to perform procedures that may exacerbate disease or that are highly invasive. These may not be ethical or easy to perform in humans. For example, treatment interruptions or intentional induction of drug resistance is likely to be harmful to an HIV-infected individual. However, understanding the effects of these procedures can lead to a better understanding of the development of drug resistance and its effects on subsequent treatment regimens. Also, obtaining organs, longitudinal blood or tissue samples, and specific time points after infection or therapy initiation cannot be acquired easily in people.

\subsection{Drug resistance}

Drug resistance in HIV-infected individuals arises from inadequate therapy, which could be the result of ineffective prescribed therapy or nonadherence. While most data on HIV-1 drug resistance have been obtained from clinical studies, the macaque model has been used to address various questions on the development and consequences of drug-resistant virus.

Because nucleoside analogs such as tenofovir and FTC inhibit SIV and have good pharmacokinetics in macaques, mutations to these drugs have been studied in the monkey model. The primary resistance mutation to FTC has been studied for its effects on in vivo viral virulence and fitness (Van Rompay et al., 2002a). Similarly, mutations conferring resistance to tenofovir were studied in SIV for their emergence and suppression in vivo during tenofovir monotherapy (Van Rompay et al., 2007). Resistant viruses were identified in macaques with breakthrough infections after intermittent tenofovir/FTC pre-exposure prophylaxis with intrarectal challenge (Garcia-Lerma et al., 2008). And FTC- and tenofovirresistant SHIV mutants were created and tested for their mucosal transmissibility (Cong et al., 2011), presumably to determine the effects of tenofovir and FTC pre-exposure prophylaxis on transmitted drug-resistant virus. 
RT-SHIVs were created to study non-nucleoside RT inhibitors, such as efavirenz, that are specific to HIV-1 but not to HIV-2 or SIV. Efavirenz monotherapy leads to the emergence of common resistance mutations that are seen in patients (Ambrose et al., 2007; Hofman et al., 2004). Efavirenz combined with tenofovir and FTC is a commonly prescribed combination therapy for HIV-infected individuals and was shown to be effective in reducing RT-SHIV plasma viremia in two species of macaques (Ambrose et al., 2007; North et al., 2005). Prior efavirenz resistance was shown to compromise combination therapy in one animal, leading to accumulation of FTC-resistant mutations in the virus and, ultimately, failure of therapy (Ambrose et al., 2007). This was similar to results described earlier in the single-dose nevirapine trials for prevention of MTCT. In addition, the RT-SHIV model allowed the study of viral subpopulation dynamics in animals, including those of drug-resistant viral variants (Shao et al., 2009).

While resistance to clinically used antiretrovirals, such as FTC, tenofovir, and efavirenz, are well documented, compounds for pre-exposure prophylaxis have also been evaluated in vivo for the ability to select for drug-resistant viruses. As stated earlier, breakthrough infections after FTC and tenofovir prophylaxis was demonstrated in macaques (GarciaLerma et al., 2008). Similarly, mutations in the SHIV envelope were observed in virus from a macaque after ineffective use of the topical entry inhibitor PSC-RANTES that conferred little or no resistance to the compound (Dudley et al., 2009). Monitoring of potential drugresistant virus is critical in preclinical and clinical studies with new inhibitors, as resistance may negatively impact efficacy of future treatment regimens.

\subsection{New delivery methods}

One complication of HIV-1 infection is the presence of large numbers of infected cells within different tissues. Although discussed more in the next section, CD4+ target cells are present within lymphoid tissues, the brain, and multiple mucosal tissues. Drug penetration into these tissues is likely to be lower than in the blood, allowing viral replication to continue within tissues. Research on better drug delivery methods into different tissues has been ongoing. This will be especially important for methods to target drugs into mucosal tissues during pre-exposure prophylaxis and also persisting viral reservoirs.

While there may be many novel delivery methods in the pipeline, only a few have been tested in vivo to specifically prevent transmission of or reduce replication of HIV-1/2. One novel delivery method of antiretrovirals to tissues is the formation and administration of drug nanocomplexes. A protease inhibitor, indinavir, was formed into nanoparticles and delivered to HIV-2-infected macaques, leading to significantly increased lymph node lymphocyte drug concentrations as compared to animals given the drug orally (Kinman et al., 2003). Nanoparticles are often cleared from the blood and tissues by phagocytic cells, such as macrophages. As macrophages are infected by HIV-1, these cells have been proposed as a target for drug delivery and phagocytosis of drug by infected cells may be beneficial. A single intravenous dose of indinavir-containing nanoparticles in mice with $\mathrm{HIV}+$ brain macrophages led to drug levels in the brain for up to 14 days and reduced virus replication in the brain (Dou et al., 2009). Nevertheless, optimization of nanocomplexes by coating their surfaces with polyethylene glycol resulted in sustained levels in the blood of mice and less clearing by macrophages (Levchenko et al., 2002). 
Another newly developed technology is the silencing of protein expression by small interfering RNAs (siRNA). siRNA can be designed to target specific mRNA in cells for degradation, leading to loss of protein expression (Hammond et al., 2000; Zamore et al., 2000). Because siRNA can be designed specifically to silence almost any RNA, they have been proposed for treatment of various diseases, including HIV-1 infection. However, targeting siRNA to specific cell types, to infected cells, and into tissues has been challenging, as they do not easily cross the plasma membrane and are quickly degraded by nucleases. Therefore, different delivery methods have been explored for more optimal targeting of siRNA to HIV-infected cells. For example, siRNA were bound to an antibody fragment that recognized HIV-1 envelope. These antibody-siRNA molecules were able to specifically target and enter envelope-expressing cells in mice (Song et al., 2005). And many techniques for introducing siRNA into nanoparticles have been tested for better pharmacokinetics, but these have been mainly preclinical studies not involving HIV-1 (reviewed in Yuan et al., 2011).

More recently, another method of delivering siRNA has been tested in both humanized mouse models to inhibit HIV-1 infection. RNA aptamer-siRNA chimeras were generated such that the aptamer portion would selectively bind to a cell surface molecule, delivering the siRNA to target cells (McNamara et al., 2006). RNA aptamers are oligonucleotides that are designed to bind tightly to specific proteins (Ellington and Szostak, 1990; Tuerk and Gold, 1990). One group used a mixture of chimeric RNAs with a CD4-binding aptamer and with siRNA targeting mRNA encoding the HIV-1 co-receptor CCR5 and viral proteins as a topical vaginal microbicide in BLT mice (Wheeler et al., 2011). The drug was able reduce CCR5 expression in vivo and resulted in a significant reduction of virus transmission. Another group used chimeric RNAs with HIV-1 envelope-binding aptamers and siRNA targeting multiple HIV-1 mRNA (Neff et al., 2011b). They were injected into HIV-1-infected Rag2 $/-\gamma \mathrm{C}-/$ humanized mice, leading to a significant reduction of both plasma viremia and CD4+ cell depletion.

The development of novel drugs and drug delivery methods is important for HIV-1 research. First, toxicity and adverse side effects of existing antiretrovirals are not trivial and should be improved to promote better adherence. Second, a lack of adherence will lead to drug resistance, which can affect multiple available treatment regimens. Third, improved prevention strategies will be necessary in the absence of a cure and in curbing the spread of HIV-1 infection among high-risk individuals. Lastly, as discussed below, targeting of new drugs to tissues to eliminate infected cells is an exciting possibility only recently realized.

\section{Animal models for targeting persisting viral reservoirs}

There is no cure for HIV-1. While HIV-infected individuals can suppress plasma viremia to undetectable levels with effective therapy, infected cells remain in the body and virus will return to the blood if therapy is halted or drug-resistance arises. The cells and tissues that harbor proviral DNA are considered viral reservoirs and are not completely characterized. Animal models allow investigators to more easily evaluate where infected cells are located and how to eradicate them than in humans.

\subsection{Evaluating viral reservoirs during antiretroviral therapy}

Because antiretroviral drugs were designed to target HIV-1, some of them are inefficient or unable to suppress SIV replication. In an animal model, antiretroviral suppression should be 
as good as what is observed in humans on combination antiretroviral therapy. Standard assays detect down to 50 copies of viral RNA per milliliter of plasma, but even with typical three drug regimens it has been difficult to completely inhibit plasma viremia in some macaques to undetectable levels (Ambrose et al., 2007; Dinoso et al., 2009; Lugli et al., 2011; North et al., 2005). The ability to achieve complete suppression generally correlates with the level of plasma viremia prior to treatment, such that higher viral loads are more difficult to completely suppress (Kearney et al., 2011). In mouse models, combination therapy has only been evaluated in humanized Rag2 $/-\gamma \mathrm{C}^{-/-}$mice, which also showed incomplete viral suppression (Choudhary et al., 2009; Sango et al., 2010). These results may be due to reduced efficacy against SIV proteins and/or different drug pharmacokinetics in macaques or mice as compared to humans.

In identifying and characterizing persistent viral reservoirs in an animal model, complete and sustained suppression is necessary. Recent reports suggest that ongoing viral replication does not occur during suppressive therapy in humans, based on a lack of viral evolution (Bailey et al., 2006; Kieffer et al., 2004; Nottet et al., 2009; Persaud et al., 2007). This was also observed in RT-SHIV-infected monkeys with sustained plasma virus suppression (Kearney et al., 2011). Continued virus replication in the presence of incomplete suppression will lead to infection of new target cells and re-seeding of reservoirs, which will interfere with identification of the actual reservoir that was established prior to initiation of therapy. This is especially important when looking at the reduction of infected cells by virus eradication therapies, as discussed below.

Despite the lack of complete suppression in many animals, the macaque model has been used to try to identify and characterize viral reservoirs. In an SIV model with FTC and tenofovir therapy, it was shown that resting CD4+ T lymphocytes from lymph nodes but not thymocytes contribute to the reservoir (Shen et al., 2003). While viral DNA was detected in multiple tissues of RT-SHIV-infected animals with and without triple therapy, very little or no viral RNA was detected in these tissues during complete suppression (North et al., 2010; Ambrose et al., unpublished results). Lymphoid and gastrointestinal tissues showed the highest level of viral DNA in virally suppressed animals, suggesting that they consist of the majority of the viral reservoir. In a model of neuropathogenic AIDS, although viremia in plasma and cerebral spinal fluid was significantly reduced by therapy, levels of viral DNA in the brains of these animals were not significantly different than the untreated controls, suggesting that virally infected cells in the central nervous system can contribute to the reservoir (Zink et al., 2010).

\subsection{Preliminary studies using animal models for eradication strategies}

To target persisting HIV-infected cells with therapeutic drugs for their eradication, one needs to know where the reservoirs are located and what types of cells are infected. While more research needs to be performed to address the type and location of infected CD4+ cells that persist and if these vary at different anatomical locations, investigators are already testing novel therapies to selectively target infected cells.

The majority of these strategies aim to stimulate latently infected, resting CD4+ cells during suppressive antiretroviral therapy. The purpose is to promote replication of virus in those cells without causing global immune activation and without leading to spread of infection to 
new cells. Histone deacetylase (HDAC) inhibitors and phorbol esters that stimulate protein kinase $\mathrm{C}$ (PKC) have received attention for their ability to activate latent HIV-1 expression in vitro (Colin and Van Lint, 2009). Clinical studies showed little or no decrease in latently infected cells or vDNA in most subjects by administration of a FDA-approved HDAC inhibitor, valproic acid, in the presence of suppressive ART (Archin et al., 2008; SagotLerolle et al., 2008; Siliciano et al., 2007). This is most likely to be a result of incorrect HDAC(s) targeting and/or inadequate drug concentrations (Huber et al., 2011; Keedy et al., 2009).

Animal models will be useful to test efficacy and mechanisms of action of potential therapies to eliminate infected cells from the body. Very recently a few studies have described the use of novel strategies in vivo and ex vivo to target viral reservoirs. Lipid nanoparticles containing the PKC activator bryostatin minimally induced proviral expression from infected CD4+ cells isolated from SCID-hu mice with thymus/liver implants (Kovochich et al., 2011). Also, a gold-based compound, auranofin, was used to treat SIV-infected macaques already receiving triple therapy (Lewis et al., 2011). After a month of treatment, PBMC proviral DNA levels decreased in the animals and plasma viral RNA was reduced after interruption of treatment.

While new eradication treatments are promising for reducing or eliminating viral reservoirs, there are many issues and remaining questions that need to be addressed. First, an assumption is that latently infected cells will die after they are activated. However, to date this has not been demonstrated in animals or in people. And it remains to be seen if there are strategies that can selectively activate HIV- or SIV-infected cells but not uninfected cells. Second, it is important to identify models or treatment options that can achieve complete, sustained virus suppression as is observed in patients. If this is achieved, methods to measure decreases in viral reservoirs will need to be optimized, including assays to measure a single copy of plasma viral RNA, a single infected cell, and spliced vs. unspliced viral RNA.

Finally, there are two caveats to the mouse and macaque models for studying persisting viral reservoirs. While mice can be rather effectively repopulated with a largely functional immune system, their anatomy is largely different than that of humans. Identification of reservoirs in mice will need to be confirmed with what is already known in humans. And although monkeys are more similar anatomically to humans, HIV-1 replication is not maintained in these animals. It remains to be seen whether transcriptional activation of SIV is similar to or different than that of HIV-1. Compounds designed to target activation of the HIV-1 LTR may not work or may work differently against SIV LTRs. Characterization of the various models for investigation of virus reservoirs should, therefore, continue.

\section{Conclusion}

This chapter has highlighted the use of macaque and mouse models for antiretroviral therapies. These animal models have improved greatly since the development of SHIVs and the ability to reconstitute a functional human immune system in mice. Refinement of these models is ongoing to make them more closely resemble humans with regards to infection, pathogenesis, and antiretroviral immunity. For example, macaque models can be improved by increased understanding of macaque cell proteins that inhibit HIV-1 infection as well as 
the genetic differences between HIV-1 and SIV, particularly the accessory proteins that appear to significantly contribute to pathogenesis. Not only will these findings make a better animal model, but virus-host cell protein interactions characterized by these studies may also lead to new therapeutic targets. Also, alterations of the current humanized mouse models to improve tissue immune cell reconstitution and anti-HIV adaptive immune responses will better recapitulate HIV-1 infection of humans.

While much work has been accomplished in HIV-1 research, questions remain for pre- and post-exposure prophylaxis, antiretroviral pharmacokinetics and efficacy, drug resistance, new drug delivery technologies, and methods for virus eradication. Using the models described here can help answer many of these questions, if used appropriately. Animal models continue to improve therapeutics against HIV-1 and they will be critical for addressing these important issues, bridging basic research together with clinical trials for HIV-1 prevention, treatment, and eradication.

\section{References}

Abdool Karim, Q., Abdool Karim, S.S., Frohlich, J.A., Grobler, A.C., Baxter, C., Mansoor, L.E., Kharsany, A.B., Sibeko, S., Mlisana, K.P., Omar, Z., et al. (2010). Effectiveness and safety of tenofovir gel, an antiretroviral microbicide, for the prevention of HIV infection in women. Science, Vol.329, No.5996, pp. 1168-1174.

Ambrose, Z., Boltz, V., Palmer, S., Coffin, J.M., Hughes, S.H., and Kewalramani, V.N. (2004). In vitro characterization of a simian immunodeficiency virus-human immunodeficiency virus (HIV) chimera expressing HIV type 1 reverse transcriptase to study antiviral resistance in pigtail macaques. Journal of Virology, Vol.78, No.24, pp. 13553-13561.

Ambrose, Z., Compton, L., Piatak, M., Jr., Lu, D., Alvord, W.G., Lubomirski, M.S., Hildreth, J.E., Lifson, J.D., Miller, C.J., and KewalRamani, V.N. (2008). Incomplete protection against simian immunodeficiency virus vaginal transmission in rhesus macaques by a topical antiviral agent revealed by repeat challenges. Journal of Virology, Vol.82, No.13, pp. 6591-6599.

Ambrose, Z., and KewalRamani, V.N. (2008). Of mice and monkeys: new advances in animal models to study HIV-1 therapy and prophylaxis. Future HIV Therapy, Vol.2, No.4, pp. 363-373.

Ambrose, Z., Palmer, S., Boltz, V.F., Kearney, M., Larsen, K., Polacino, P., Flanary, L., Oswald, K., Piatak, M., Smedley, J., et al. (2007). Suppression of viremia and evolution of human immunodeficiency virus type 1 drug resistance in a macaque model for antiretroviral therapy. Journal of Virology, Vol.81, No.22, pp. 12145-12155.

Archin, N.M., Eron, J.J., Palmer, S., Hartmann-Duff, A., Martinson, J.A., Wiegand, A., Bandarenko, N., Schmitz, J.L., Bosch, R.J., Landay, A.L., et al. (2008). Valproic acid without intensified antiviral therapy has limited impact on persistent HIV infection of resting CD4+ T cells. AIDS, Vol.22, No.10, pp. 1131-1135.

Baba, T.W., Liska, V., Hofmann-Lehmann, R., Vlasak, J., Xu, W., Ayehunie, S., Cavacini, L.A., Posner, M.R., Katinger, H., Stiegler, G., et al. (2000). Human neutralizing monoclonal antibodies of the IgG1 subtype protect against mucosal simian-human immunodeficiency virus infection. Nature Medicine, Vol.6, No.2, pp. 200-206. 
Baenziger, S., Tussiwand, R., Schlaepfer, E., Mazzucchelli, L., Heikenwalder, M., Kurrer, M.O., Behnke, S., Frey, J., Oxenius, A., Joller, H., et al. (2006). Disseminated and sustained HIV infection in CD34+ cord blood cell-transplanted Rag2-/-gamma c-/mice. Proceedings of the National Academy of Sciences USA, Vol.103, No.43, pp. 1595115956.

Bailey, J.R., Sedaghat, A.R., Kieffer, T., Brennan, T., Lee, P.K., Wind-Rotolo, M., Haggerty, C.M., Kamireddi, A.R., Liu, Y., Lee, J., et al. (2006). Residual human immunodeficiency virus type 1 viremia in some patients on antiretroviral therapy is dominated by a small number of invariant clones rarely found in circulating CD4+ T cells. Journal of Virology, Vol.80, No.13, pp. 6441-6457.

Balani, S.K., Kauffman, L.R., deLuna, F.A., and Lin, J.H. (1999). Nonlinear pharmacokinetics of efavirenz (DMP-266), a potent HIV-1 reverse transcriptase inhibitor, in rats and monkeys. Drug Metabolism and Disposition: the Biological Fate of Chemicals, Vol.27, No.1, pp. 41-45.

Balzarini, J., Naesens, L., Slachmuylders, J., Niphuis, H., Rosenberg, I., Holy, A., Schellekens, H., and De Clercq, E. (1991). 9-(2-Phosphonylmethoxyethyl)adenine (PMEA) effectively inhibits retrovirus replication in vitro and simian immunodeficiency virus infection in rhesus monkeys. AIDS, Vol.5, No.1, pp. 21-28.

Barnett, S.W., Murthy, K.K., Herndier, B.G., and Levy, J.A. (1994). An AIDS-like condition induced in baboons by HIV-2. Science, Vol.266, No.5185, pp. 642-646.

Berges, B.K., Akkina, S.R., Folkvord, J.M., Connick, E., and Akkina, R. (2008). Mucosal transmission of R5 and X4 tropic HIV-1 via vaginal and rectal routes in humanized Rag2-/- gammac -/- (RAG-hu) mice. Virology, Vol.373, No.2, pp. 342-351.

Boadi, T., Schneider, E., Chung, S., Tsai, L., Gettie, A., Ratterree, M., Blanchard, J., Neurath, A.R., and Cheng-Mayer, C. (2005). Cellulose acetate 1,2-benzenedicarboxylate protects against challenge with pathogenic $\mathrm{X} 4$ and $\mathrm{R} 5$ simian/human immunodeficiency virus. AIDS, Vol.19, No.15, pp. 1587-1594.

Bourry, O., Brochard, P., Souquiere, S., Makuwa, M., Calvo, J., Dereudre-Bosquet, N., Martinon, F., Benech, H., Kazanji, M., and Le Grand, R. (2009). Prevention of vaginal simian immunodeficiency virus transmission in macaques by postexposure prophylaxis with zidovudine, lamivudine and indinavir. AIDS, Vol.23, No.4, pp. 447-454.

Choudhary, S.K., Rezk, N.L., Ince, W.L., Cheema, M., Zhang, L., Su, L., Swanstrom, R., Kashuba, A.D., and Margolis, D.M. (2009). Suppression of human immunodeficiency virus type 1 (HIV-1) viremia with reverse transcriptase and integrase inhibitors, CD4+ T-cell recovery, and viral rebound upon interruption of therapy in a new model for HIV treatment in the humanized Rag2-/-\{gamma\}c-/- mouse. Journal of Virology, Vol.83, No.16, pp. 8254-8258.

Colin, L., and Van Lint, C. (2009). Molecular control of HIV-1 postintegration latency: implications for the development of new therapeutic strategies. Retrovirology, Vol.6, p. 111.

Cong, M.E., Youngpairoj, A.S., Aung, W., Sharma, S., Mitchell, J., Dobard, C., Heneine, W., and Garcia-Lerma, J.G. (2011). Generation and mucosal transmissibility of emtricitabine- and tenofovir-resistant SHIV162P3 mutants in macaques. Virology, Vol.412, No.2, pp. 435-440.

Connor, E.M., Sperling, R.S., Gelber, R., Kiselev, P., Scott, G., O'Sullivan, M.J., VanDyke, R., Bey, M., Shearer, W., Jacobson, R.L., et al. (1994). Reduction of maternal-infant 
transmission of human immunodeficiency virus type 1 with zidovudine treatment. Pediatric AIDS Clinical Trials Group Protocol 076 Study Group. New England Journal of Medicine, Vol.331, No.18, pp. 1173-1180.

Cranage, M., Sharpe, S., Herrera, C., Cope, A., Dennis, M., Berry, N., Ham, C., Heeney, J., Rezk, N., Kashuba, A., et al. (2008). Prevention of SIV rectal transmission and priming of $\mathrm{T}$ cell responses in macaques after local pre-exposure application of tenofovir gel. PLoS Medicine, Vol.5, No.8, pp. e157.

Daniel, M.D., Letvin, N.L., King, N.W., Kannagi, M., Sehgal, P.K., Hunt, R.D., Kanki, P.J., Essex, M., and Desrosiers, R.C. (1985). Isolation of T-cell tropic HTLV-III-like retrovirus from macaques. Science, Vol.228, No.4704, pp. 1201-1204.

Denton, P.W., Estes, J.D., Sun, Z., Othieno, F.A., Wei, B.L., Wege, A.K., Powell, D.A., Payne, D., Haase, A.T., and Garcia, J.V. (2008). Antiretroviral pre-exposure prophylaxis prevents vaginal transmission of HIV-1 in humanized BLT mice. PLoS Medicine, Vol.5, No.1, p. e16.

Denton, P.W., Krisko, J.F., Powell, D.A., Mathias, M., Kwak, Y.T., Martinez-Torres, F., Zou, W., Payne, D.A., Estes, J.D., and Garcia, J.V. (2010). Systemic administration of antiretrovirals prior to exposure prevents rectal and intravenous HIV-1 transmission in humanized BLT mice. PLoS One, Vol.5, No.1, p. e8829.

Denton, P.W., Othieno, F., Martinez-Torres, F., Zou, W., Krisko, J.F., Fleming, E., Zein, S., Powell, D.A., Wahl, A., Kwak, Y.T., et al. (2011). One Percent Tenofovir Applied Topically to Humanized BLT Mice and Used According to the CAPRISA 004 Experimental Design Demonstrates Partial Protection from Vaginal HIV Infection, Validating the BLT Model for Evaluation of New Microbicide Candidates. Journal of Virology, Vol.85, No.15, pp. 7582-7593.

Dinoso, J.B., Rabi, S.A., Blankson, J.N., Gama, L., Mankowski, J.L., Siliciano, R.F., Zink, M.C., and Clements, J.E. (2009). A simian immunodeficiency virus-infected macaque model to study viral reservoirs that persist during highly active antiretroviral therapy. Journal of Virology, Vol.83, No.18, pp. 9247-9257.

Dou, H., Grotepas, C.B., McMillan, J.M., Destache, C.J., Chaubal, M., Werling, J., Kipp, J., Rabinow, B., and Gendelman, H.E. (2009). Macrophage delivery of nanoformulated antiretroviral drug to the brain in a murine model of neuroAIDS. Journal of Immunology, Vol.183, No.1, pp. 661-669.

Dudley, D.M., Wentzel, J.L., Lalonde, M.S., Veazey, R.S., and Arts, E.J. (2009). Selection of a simian-human immunodeficiency virus strain resistant to a vaginal microbicide in macaques. Journal of Virology, Vol.83, No.10, pp. 5067-5076.

Ellington, A.D., and Szostak, J.W. (1990). In vitro selection of RNA molecules that bind specific ligands. Nature 346,6287, 818-822.

Eshleman, S.H., Mracna, M., Guay, L.A., Deseyve, M., Cunningham, S., Mirochnick, M., Musoke, P., Fleming, T., Glenn Fowler, M., Mofenson, L.M., et al. (2001). Selection and fading of resistance mutations in women and infants receiving nevirapine to prevent HIV-1 vertical transmission (HIVNET 012). AIDS, Vol.15, No.15, pp. 19511957.

Fazely, F., Haseltine, W.A., Rodger, R.F., and Ruprecht, R.M. (1991). Postexposure chemoprophylaxis with ZDV or ZDV combined with interferon-alpha: failure after inoculating rhesus monkeys with a high dose of SIV. Journal of Acquired Immune Deficiency Syndromes, Vol.4, No.11, pp. 1093-1097. 
Ferrantelli, F., Rasmussen, R.A., Buckley, K.A., Li, P.L., Wang, T., Montefiori, D.C., Katinger, H., Stiegler, G., Anderson, D.C., McClure, H.M., et al. (2004). Complete protection of neonatal rhesus macaques against oral exposure to pathogenic simian-human immunodeficiency virus by human anti-HIV monoclonal antibodies. Journal of Infectious Diseases, Vol.189, No.12, pp. 2167-2173.

Flys, T., Nissley, D.V., Claasen, C.W., Jones, D., Shi, C., Guay, L.A., Musoke, P., Mmiro, F., Strathern, J.N., Jackson, J.B., et al. (2005). Sensitive drug-resistance assays reveal long-term persistence of HIV-1 variants with the K103N nevirapine (NVP) resistance mutation in some women and infants after the administration of singledose NVP: HIVNET 012. Journal of Infectious Diseases, Vol.192, No.1, pp. 24-29.

Garcia-Lerma, J.G., Otten, R.A., Qari, S.H., Jackson, E., Cong, M.E., Masciotra, S., Luo, W., Kim, C., Adams, D.R., Monsour, M., et al. (2008). Prevention of rectal SHIV transmission in macaques by daily or intermittent prophylaxis with emtricitabine and tenofovir. PLoS Medicine, Vol.5, No.2, p. e28.

Gardelli, C., Nizi, E., Muraglia, E., Crescenzi, B., Ferrara, M., Orvieto, F., Pace, P., Pescatore, G., Poma, M., Ferreira Mdel, R., et al. (2007). Discovery and synthesis of HIV integrase inhibitors: development of potent and orally bioavailable $\mathrm{N}$-methyl pyrimidones. Journal of Medicinal Chemistry, Vol.50, No.20, pp. 4953-4975.

Grant, R.M., Lama, J.R., Anderson, P.L., McMahan, V., Liu, A.Y., Vargas, L., Goicochea, P., Casapia, M., Guanira-Carranza, J.V., Ramirez-Cardich, M.E., et al. (2010). Preexposure chemoprophylaxis for HIV prevention in men who have sex with men. New England Journal of Medicine, Vol.363, No.27, pp. 2587-2599.

Guay, L.A., Musoke, P., Fleming, T., Bagenda, D., Allen, M., Nakabiito, C., Sherman, J., Bakaki, P., Ducar, C., Deseyve, M., et al. (1999). Intrapartum and neonatal singledose nevirapine compared with zidovudine for prevention of mother-to-child transmission of HIV-1 in Kampala, Uganda: HIVNET 012 randomised trial. The Lancet, Vol.354, No.9181, pp. 795-802.

Gupta, P., Mellors, J., Kingsley, L., Riddler, S., Singh, M.K., Schreiber, S., Cronin, M., and Rinaldo, C.R. (1997). High viral load in semen of human immunodeficiency virus type 1-infected men at all stages of disease and its reduction by therapy with protease and nonnucleoside reverse transcriptase inhibitors. Journal of Virology, Vol.71, No.8, pp. 6271-6275.

Hammond, S.M., Bernstein, E., Beach, D., and Hannon, G.J. (2000). An RNA-directed nuclease mediates post-transcriptional gene silencing in Drosophila cells. Nature, Vol.404, No.6775, pp. 293-296.

Hatziioannou, T., Ambrose, Z., Chung, N.P., Piatak, M., Jr., Yuan, F., Trubey, C.M., Coalter, V., Kiser, R., Schneider, D., Smedley, J., et al. (2009). A macaque model of HIV-1 infection. Proceedings of the National Academy of Sciences USA, Vol.106, No.11, pp. 4425-4429.

Hazuda, D.J., Young, S.D., Guare, J.P., Anthony, N.J., Gomez, R.P., Wai, J.S., Vacca, J.P., Handt, L., Motzel, S.L., Klein, H.J., et al. (2004). Integrase inhibitors and cellular immunity suppress retroviral replication in rhesus macaques. Science, Vol.305, No.5683, pp. 528-532.

Hicks, D.R., Martin, L.S., Getchell, J.P., Heath, J.L., Francis, D.P., McDougal, J.S., Curran, J.W., and Voeller, B. (1985). Inactivation of HTLV-III/LAV-infected cultures of normal human lymphocytes by nonoxynol-9 in vitro. The Lancet, Vol.2, No.8469-70, pp. 1422-1423. 
Hirsch, V.M., Olmsted, R.A., Murphey-Corb, M., Purcell, R.H., and Johnson, P.R. (1989). An African primate lentivirus (SIVsm) closely related to HIV-2. Nature, Vol.339, No.6223, pp. 389-392.

Ho, R.J., Larsen, K., Bui, T., Wang, X.Y., Herz, A.M., Sherbert, C., Finn, E., Nosbisch, C., Schmidt, A., Anderson, D., et al. (2000). Suppression of maternal virus load with zidovudine, didanosine, and indinavir combination therapy prevents mother-tofetus HIV transmission in macaques. Journal of Acquired Immune Deficiency Syndromes, Vol.25, No.2, pp. 140-149.

Hofman, M.J., Higgins, J., Matthews, T.B., Pedersen, N.C., Tan, C., Schinazi, R.F., and North, T.W. (2004). Efavirenz therapy in rhesus macaques infected with a chimera of simian immunodeficiency virus containing reverse transcriptase from human immunodeficiency virus type 1. Antimicrobial Agents and Chemotherapy, Vol.48, No.9, pp. 3483-3490.

Hofmann-Lehmann, R., Vlasak, J., Rasmussen, R.A., Smith, B.A., Baba, T.W., Liska, V., Ferrantelli, F., Montefiori, D.C., McClure, H.M., Anderson, D.C., et al. (2001). Postnatal passive immunization of neonatal macaques with a triple combination of human monoclonal antibodies against oral simian-human immunodeficiency virus challenge. Journal of Virology, Vol.75, No.16, pp. 7470-7480.

Huber, K., Doyon, G., Plaks, J., Fyne, E., Mellors, J.W., and Sluis-Cremer, N. (2011). Inhibitors of Histone Deacetylases: correlation between isoform specificity and HIV type 1 (HIV-1) from latently infected cells. Journal of Biological Chemistry, Vol.286, No.25, pp. 22211-22218.

Igarashi, T., Iyengar, R., Byrum, R.A., Buckler-White, A., Dewar, R.L., Buckler, C.E., Lane, H.C., Kamada, K., Adachi, A., and Martin, M.A. (2007). Human immunodeficiency virus type 1 derivative with $7 \%$ simian immunodeficiency virus genetic content is able to establish infections in pig-tailed macaques. Journal of Virology, Vol.81, No.20, pp. 11549-11552.

Jourdain, G., Ngo-Giang-Huong, N., Le Coeur, S., Bowonwatanuwong, C., Kantipong, P., Leechanachai, P., Ariyadej, S., Leenasirimakul, P., Hammer, S., and Lallemant, M. (2004). Intrapartum exposure to nevirapine and subsequent maternal responses to nevirapine-based antiretroviral therapy. New England Journal of Medicine, Vol.351, No.3, pp. 229-240.

Kaldor, S.W., Kalish, V.J., Davies, J.F., 2nd, Shetty, B.V., Fritz, J.E., Appelt, K., Burgess, J.A., Campanale, K.M., Chirgadze, N.Y., Clawson, D.K., et al. (1997). Viracept (nelfinavir mesylate, AG1343): a potent, orally bioavailable inhibitor of HIV-1 protease. Journal of Medicinal Chemistry, Vol.40, No.24, pp. 3979-3985.

Kanki, P.J., McLane, M.F., King, N.W., Jr., Letvin, N.L., Hunt, R.D., Sehgal, P., Daniel, M.D., Desrosiers, R.C., and Essex, M. (1985). Serologic identification and characterization of a macaque T-lymphotropic retrovirus closely related to HTLV-III. Science, Vol.228, No.4704, pp. 1199-1201.

Kearney, M., Spindler, J., Shao, W., Maldarelli, F., Palmer, S., Hu, S.L., Lifson, J.D., KewalRamani, V.N., Mellors, J.W., Coffin, J.M., et al. (2011). Genetic diversity of simian immunodeficiency virus encoding HIV-1 reverse transcriptase persists in macaques despite antiretroviral therapy. Journal of Virology, Vol.85, No.2, pp. 10671076.

Keedy, K.S., Archin, N.M., Gates, A.T., Espeseth, A., Hazuda, D.J., and Margolis, D.M. (2009). A limited group of class I histone deacetylases acts to repress human 
immunodeficiency virus type 1 expression. Journal of Virology, Vol.83, No.10, pp. 4749-4756.

Keele, B.F., Van Heuverswyn, F., Li, Y., Bailes, E., Takehisa, J., Santiago, M.L., BibolletRuche, F., Chen, Y., Wain, L.V., Liegeois, F., et al. (2006). Chimpanzee reservoirs of pandemic and nonpandemic HIV-1. Science, Vol.313, No.5786, pp. 523-526.

Keller, R.D., Nosbisch, C., and Unadkat, J.D. (1995). Pharmacokinetics of stavudine (2',3'didehydro-3'-deoxythymidine) in the neonatal macaque (Macaca nemestrina). Antimicrobial Agents and Chemotherapy, Vol.39, No.12, pp. 2829-2831.

Kelley, J.A., Litterst, C.L., Roth, J.S., Vistica, D.T., Poplack, D.G., Cooney, D.A., Nadkarni, M., Balis, F.M., Broder, S., and Johns, D.G. (1987). The disposition and metabolism of 2',3'-dideoxycytidine, an in vitro inhibitor of human T-lymphotrophic virus type III infectivity, in mice and monkeys. Drug Metabolism and Disposition: the Biological Fate of Chemicals, Vol.15, No.5, pp. 595-601.

Kenney, J., Aravantinou, M., Singer, R., Hsu, M., Rodriguez, A., Kizima, L., Abraham, C.J., Menon, R., Seidor, S., Chudolij, A., et al. (2011). An antiretroviral/zinc combination gel provides 24 hours of complete protection against vaginal SHIV infection in macaques. PLoS One, vol.6, no.1, p. e15835.

Kieffer, T.L., Finucane, M.M., Nettles, R.E., Quinn, T.C., Broman, K.W., Ray, S.C., Persaud, D., and Siliciano, R.F. (2004). Genotypic analysis of HIV-1 drug resistance at the limit of detection: virus production without evolution in treated adults with undetectable HIV loads. Journal of Infectious Diseases, Vol.189, No.8, pp. 1452-1465.

Kim, C.N., Adams, D.R., Bashirian, S., Butera, S., Folks, T.M., and Otten, R.A. (2006). Repetitive exposures with simian/human immunodeficiency viruses: strategy to study HIV pre-clinical interventions in non-human primates. Journal of Medical Primatology, Vol.35, No.4-5, pp. 210-216.

Kinman, L., Brodie, S.J., Tsai, C.C., Bui, T., Larsen, K., Schmidt, A., Anderson, D., Morton, W.R., Hu, S.L., and Ho, R.J. (2003). Lipid-drug association enhanced HIV-1 protease inhibitor indinavir localization in lymphoid tissues and viral load reduction: a proof of concept study in HIV-2287-infected macaques. Journal of Acquired Immune Deficiency Syndromes, Vol.34, No.4, pp. 387-397.

Kish-Catalone, T., Pal, R., Parrish, J., Rose, N., Hocker, L., Hudacik, L., Reitz, M., Gallo, R., and Devico, A. (2007). Evaluation of -2 RANTES vaginal microbicide formulations in a nonhuman primate simian/human immunodeficiency virus (SHIV) challenge model. AIDS Research and Human Retroviruses, Vol.23, No.1, pp. 33-42.

Kovochich, M., Marsden, M.D., and Zack, J.A. (2011). Activation of latent HIV using drugloaded nanoparticles. PLoS One, Vol.6, No.4, p. e18270.

Kwara, A., Delong, A., Rezk, N., Hogan, J., Burtwell, H., Chapman, S., Moreira, C.C., Kurpewski, J., Ingersoll, J., Caliendo, A.M., et al. (2008). Antiretroviral drug concentrations and HIV RNA in the genital tract of HIV-infected women receiving long-term highly active antiretroviral therapy. Clinical Infectious Diseases, Vol.46, No.5, pp. 719-725.

Lagenaur, L.A., Sanders-Beer, B.E., Brichacek, B., Pal, R., Liu, X., Liu, Y., Yu, R., Venzon, D., Lee, P.P., and Hamer, D.H. (2011). Prevention of vaginal SHIV transmission in macaques by a live recombinant Lactobacillus. Mucosal Immunology, July 6, epub ahead of print.

Le Grand, R., Vaslin, B., Larghero, J., Neidez, O., Thiebot, H., Sellier, P., Clayette, P., Dereuddre-Bosquet, N., and Dormont, D. (2000). Post-exposure prophylaxis with 
highly active antiretroviral therapy could not protect macaques from infection with SIV/HIV chimera. AIDS, Vol.14, No.12, pp. 1864-1866.

Lederman, M.M., Veazey, R.S., Offord, R., Mosier, D.E., Dufour, J., Mefford, M., Piatak, M., Jr., Lifson, J.D., Salkowitz, J.R., Rodriguez, B., et al. (2004). Prevention of vaginal SHIV transmission in rhesus macaques through inhibition of CCR5. Science, Vol.306, No.5695, pp. 485-487.

Levchenko, T.S., Rammohan, R., Lukyanov, A.N., Whiteman, K.R., and Torchilin, V.P. (2002). Liposome clearance in mice: the effect of a separate and combined presence of surface charge and polymer coating. International Journal of Pharmaceutics, Vol.240, No.1-2, pp. 95-102.

Lewis, M.G., Dafonseca, S., Chomont, N., Palamara, A.T., Tardugno, M., Mai, A., Collins, M., Wagner, W.L., Yalley-Ogunro, J., Greenhouse, J., et al. (2011). Gold drug auranofin restricts the viral reservoir in the monkey AIDS model and induces containment of viral load following ART suspension. AIDS, Vol.25, No.11, pp. 1347-1356.

Li, J., Lord, C.I., Haseltine, W., Letvin, N.L., and Sodroski, J. (1992). Infection of cynomolgus monkeys with a chimeric HIV-1/SIVmac virus that expresses the HIV-1 envelope glycoproteins. Journal of Acquired Immune Deficiency Syndromes, Vol.5, No.7, pp. 639646.

Li, Q., Estes, J.D., Schlievert, P.M., Duan, L., Brosnahan, A.J., Southern, P.J., Reilly, C.S., Peterson, M.L., Schultz-Darken, N., Brunner, K.G., et al. (2009). Glycerol monolaurate prevents mucosal SIV transmission. Nature, Vol.458, No.7241, pp. 1034-1038.

Lifson, J.D., Piatak, M., Jr., Cline, A.N., Rossio, J.L., Purcell, J., Pandrea, I., Bischofberger, N., Blanchard, J., and Veazey, R.S. (2003). Transient early post-inoculation antiretroviral treatment facilitates controlled infection with sparing of CD4+ T cells in gut-associated lymphoid tissues in SIVmac239-infected rhesus macaques, but not resistance to rechallenge. Journal of Medical Primatology, Vol.32, No.4-5, pp. 201-210.

Liuzzi, G., Chirianni, A., Clementi, M., Bagnarelli, P., Valenza, A., Cataldo, P.T., and Piazza, M. (1996). Analysis of HIV-1 load in blood, semen and saliva: evidence for different viral compartments in a cross-sectional and longitudinal study. AIDS, Vol.10, No.14, pp. F51-56.

Lu, Y., Brosio, P., Lafaile, M., Li, J., Collman, R.G., Sodroski, J., and Miller, C.J. (1996). Vaginal transmission of chimeric simian/human immunodeficiency viruses in rhesus macaques. Journal of Virology, Vol.70, No.5, pp. 3045-3050.

Luciw, P.A., Pratt-Lowe, E., Shaw, K.E., Levy, J.A., and Cheng-Mayer, C. (1995). Persistent infection of rhesus macaques with T-cell-line-tropic and macrophage-tropic clones of simian/human immunodeficiency viruses (SHIV). Proceedings of the National Academy of Sciences USA, Vol.92, No.16, pp. 7490-7494.

Lugli, E., Mueller, Y.M., Lewis, M.G., Villinger, F., Katsikis, P.D., and Roederer, M. (2011). Interleukin-15 delays suppression and fails to promote immune reconstitution in virally suppressed chronically SIV-infected macaques. Blood, July 14, epub ahead of print.

Manson, K.H., Wyand, M.S., Miller, C., and Neurath, A.R. (2000). Effect of a cellulose acetate phthalate topical cream on vaginal transmission of simian immunodeficiency virus in rhesus monkeys. Antimicrobial Agents and Chemotherapy, Vol.44, No.11, pp. 3199-3202. 
Mariani, R., Chen, D., Schrofelbauer, B., Navarro, F., Konig, R., Bollman, B., Munk, C., Nymark-McMahon, H., and Landau, N.R. (2003). Species-specific exclusion of APOBEC3G from HIV-1 virions by Vif. Cell, Vol.114, No.1, pp. 21-31.

Marthas, M.L., Lu, D., Penedo, M.C., Hendrickx, A.G., and Miller, C.J. (2001). Titration of an SIVmac251 stock by vaginal inoculation of Indian and Chinese origin rhesus macaques: transmission efficiency, viral loads, and antibody responses. AIDS Research and Human Retroviruses, Vol.17, No.15, pp. 1455-1466.

Mascola, J.R., Stiegler, G., VanCott, T.C., Katinger, H., Carpenter, C.B., Hanson, C.E., Beary, H., Hayes, D., Frankel, S.S., Birx, D.L., et al. (2000). Protection of macaques against vaginal transmission of a pathogenic HIV-1/SIV chimeric virus by passive infusion of neutralizing antibodies. Nature Medicine, Vol.6, No.2, pp. 207-210.

McNamara, J.O., 2nd, Andrechek, E.R., Wang, Y., Viles, K.D., Rempel, R.E., Gilboa, E., Sullenger, B.A., and Giangrande, P.H. (2006). Cell type-specific delivery of siRNAs with aptamer-siRNA chimeras. Nature Biotechnology, Vol.24, No.8, pp. 1005-1015.

Mosier, D.E., Gulizia, R.J., Baird, S.M., and Wilson, D.B. (1988). Transfer of a functional human immune system to mice with severe combined immunodeficiency. Nature, Vol.335, No.6187, pp. 256-259.

Musoke, P., Guay, L.A., Bagenda, D., Mirochnick, M., Nakabiito, C., Fleming, T., Elliott, T., Horton, S., Dransfield, K., Pav, J.W., et al. (1999). A phase I/II study of the safety and pharmacokinetics of nevirapine in HIV-1-infected pregnant Ugandan women and their neonates (HIVNET 006). AIDS, Vol.13, No.4, pp. 479-486.

Namikawa, R., Weilbaecher, K.N., Kaneshima, H., Yee, E.J., and McCune, J.M. (1990). Longterm human hematopoiesis in the SCID-hu mouse. Journal of Experimental Medicine, Vol.172, No.4, pp. 1055-1063.

Neff, C.P., Kurisu, T., Ndolo, T., Fox, K., and Akkina, R. (2011a). A Topical Microbicide Gel Formulation of CCR5 Antagonist Maraviroc Prevents HIV-1 Vaginal Transmission in Humanized RAG-hu Mice. PLoS One, Vol.6, No.6, p. e20209.

Neff, C.P., Ndolo, T., Tandon, A., Habu, Y., and Akkina, R. (2010). Oral pre-exposure prophylaxis by anti-retrovirals raltegravir and maraviroc protects against HIV-1 vaginal transmission in a humanized mouse model. PLoS One, Vol.5, No.12, p. e15257.

Neff, C.P., Zhou, J., Remling, L., Kuruvilla, J., Zhang, J., Li, H., Smith, D.D., Swiderski, P., Rossi, J.J., and Akkina, R. (2011b). An aptamer-siRNA chimera suppresses HIV-1 viral loads and protects from helper CD4(+) $\mathrm{T}$ cell decline in humanized mice. Science Translational Medicine, Vol.3, No.66, p. 66ra66.

Nishimura, Y., Igarashi, T., Haigwood, N.L., Sadjadpour, R., Donau, O.K., Buckler, C., Plishka, R.J., Buckler-White, A., and Martin, M.A. (2003). Transfer of neutralizing IgG to macaques $6 \mathrm{~h}$ but not $24 \mathrm{~h}$ after SHIV infection confers sterilizing protection: implications for HIV-1 vaccine development. Proceedings of the National Academy of Sciences USA, Vol.100, No.25, pp. 15131-15136.

North, T.W., Higgins, J., Deere, J.D., Hayes, T.L., Villalobos, A., Adamson, L., Shacklett, B.L., Schinazi, R.F., and Luciw, P.A. (2010). Viral sanctuaries during highly active antiretroviral therapy in a nonhuman primate model for AIDS. Journal of Virology, Vol.84, No.6, pp. 2913-2922.

North, T.W., Van Rompay, K.K., Higgins, J., Matthews, T.B., Wadford, D.A., Pedersen, N.C., and Schinazi, R.F. (2005). Suppression of virus load by highly active antiretroviral therapy in rhesus macaques infected with a recombinant simian immunodeficiency 
virus containing reverse transcriptase from human immunodeficiency virus type 1 . Journal of Virology, Vol.79, No.12, pp. 7349-7354.

Nottet, H.S., van Dijk, S.J., Fanoy, E.B., Goedegebuure, I.W., de Jong, D., Vrisekoop, N., van Baarle, D., Boltz, V., Palmer, S., Borleffs, J.C., et al. (2009). HIV-1 can persist in aged memory CD4+ T lymphocytes with minimal signs of evolution after 8.3 years of effective highly active antiretroviral therapy. Journal of Acquired Immune Deficiency Syndromes, Vol.50, No.4, pp. 345-353.

Novembre, F.J., Saucier, M., Anderson, D.C., Klumpp, S.A., O'Neil, S.P., Brown, C.R., 2nd, Hart, C.E., Guenthner, P.C., Swenson, R.B., and McClure, H.M. (1997). Development of AIDS in a chimpanzee infected with human immunodeficiency virus type 1. Journal of Virology, Vol.71, No.5, pp. 4086-4091.

Otten, R.A., Smith, D.K., Adams, D.R., Pullium, J.K., Jackson, E., Kim, C.N., Jaffe, H., Janssen, R., Butera, S., and Folks, T.M. (2000). Efficacy of postexposure prophylaxis after intravaginal exposure of pig-tailed macaques to a human-derived retrovirus (human immunodeficiency virus type 2). Journal of Virology, Vol.74, No.20, pp. 9771-9775.

Pace, P., Di Francesco, M.E., Gardelli, C., Harper, S., Muraglia, E., Nizi, E., Orvieto, F., Petrocchi, A., Poma, M., Rowley, M., et al. (2007). Dihydroxypyrimidine-4carboxamides as novel potent and selective HIV integrase inhibitors. Journal of Medicinal Chemistry, Vol.50, No.9, pp. 2225-2239.

Paiardini, M., Pandrea, I., Apetrei, C., and Silvestri, G. (2009). Lessons learned from the natural hosts of HIV-related viruses. Annual Review of Medicine, Vol.60, pp. 485-495.

Palmer, S., Boltz, V., Martinson, N., Maldarelli, F., Gray, G., McIntyre, J., Mellors, J., Morris, L., and Coffin, J. (2006). Persistence of nevirapine-resistant HIV-1 in women after singledose nevirapine therapy for prevention of maternal-to-fetal HIV-1 transmission. Proceedings of the National Academy of Sciences USA, Vol.103, No.18, pp. 7094-7099.

Parikh, U.M., Dobard, C., Sharma, S., Cong, M.E., Jia, H., Martin, A., Pau, C.P., Hanson, D.L., Guenthner, P., Smith, J., et al. (2009). Complete protection from repeated vaginal simian-human immunodeficiency virus exposures in macaques by a topical gel containing tenofovir alone or with emtricitabine. Journal of Virology, Vol.83, No.20, pp. 10358-10365.

Parren, P.W., Marx, P.A., Hessell, A.J., Luckay, A., Harouse, J., Cheng-Mayer, C., Moore, J.P., and Burton, D.R. (2001). Antibody protects macaques against vaginal challenge with a pathogenic R5 simian/human immunodeficiency virus at serum levels giving complete neutralization in vitro. Journal of Virology, Vol.75, No.17, pp. 8340-8347.

Patton, D.L., Cosgrove Sweeney, Y.T., Rabe, L.K., and Hillier, S.L. (2002). Rectal applications of nonoxynol-9 cause tissue disruption in a monkey model. Sexually Transmitted Diseases, Vol.29, No.10, pp. 581-587.

Patton, D.L., Kidder, G.G., Sweeney, Y.C., Rabe, L.K., and Hillier, S.L. (1999). Effects of multiple applications of benzalkonium chloride and nonoxynol 9 on the vaginal epithelium in the pigtailed macaque (Macaca nemestrina). American Journal of Obstetrics and Gynecology, Vol.180, No.5, pp. 1080-1087.

Persaud, D., Ray, S.C., Kajdas, J., Ahonkhai, A., Siberry, G.K., Ferguson, K., Ziemniak, C., Quinn, T.C., Casazza, J.P., Zeichner, S., et al. (2007). Slow human immunodeficiency virus type 1 evolution in viral reservoirs in infants treated with effective antiretroviral therapy. AIDS Research and Human Retroviruses, Vol.23, No.3, pp. 381-390. 
Phillips, D.M., Taylor, C.L., Zacharopoulos, V.R., and Maguire, R.A. (2000). Nonoxynol-9 causes rapid exfoliation of sheets of rectal epithelium. Contraception, Vol.62, No.3, pp. 149-154.

Reimann, K.A., Li, J.T., Veazey, R., Halloran, M., Park, I.W., Karlsson, G.B., Sodroski, J., and Letvin, N.L. (1996). A chimeric simian/human immunodeficiency virus expressing a primary patient human immunodeficiency virus type 1 isolate env causes an AIDS-like disease after in vivo passage in rhesus monkeys. Journal of Virology, Vol.70, No.10, pp. 6922-6928.

Roehr, B. (2011). Tenofovir works as pre-exposure prophylaxis against HIV, two studies confirm. BMJ, Vol.343, p. d4540.

Sagot-Lerolle, N., Lamine, A., Chaix, M.L., Boufassa, F., Aboulker, J.P., Costagliola, D., Goujard, C., Pallier, C., Delfraissy, J.F., and Lambotte, O. (2008). Prolonged valproic acid treatment does not reduce the size of latent HIV reservoir. AIDS, Vol.22, No.10, pp. 1125-1129.

Sango, K., Joseph, A., Patel, M., Osiecki, K., Dutta, M., and Goldstein, H. (2010). Highly active antiretroviral therapy potently suppresses HIV infection in humanized Rag2-/gammac-/- mice. AIDS Research and Human Retroviruses, Vol.26, No.7, pp. 735-746.

Sato, S., and Johnson, W. (2007). Antibody-mediated neutralization and simian immunodeficiency virus models of HIV/AIDS. Current HIV Research, Vol.5, No.6, pp. 594-607.

Shao, W., Kearney, M., Maldarelli, F., Mellors, J.W., Stephens, R., Lifson, J.D., KewalRamani, V.N., Ambrose, Z., Coffin, J.M., and Palmer, S. (2009). RT-SHIV subpopulation dynamics during anti-HIV-1 therapy. Retrovirology, Vol.6, p. 101.

Shen, A., Zink, M.C., Mankowski, J.L., Chadwick, K., Margolick, J.B., Carruth, L.M., Li, M., Clements, J.E., and Siliciano, R.F. (2003). Resting CD4+ T lymphocytes but not thymocytes provide a latent viral reservoir in a simian immunodeficiency virusMacaca nemestrina model of human immunodeficiency virus type 1-infected patients on highly active antiretroviral therapy. Journal of Virology, Vol.77, No.8, pp. 4938-4949.

Shibata, R., Kawamura, M., Sakai, H., Hayami, M., Ishimoto, A., and Adachi, A. (1991). Generation of a chimeric human and simian immunodeficiency virus infectious to monkey peripheral blood mononuclear cells. Journal of Virology, Vol.65, No.7, pp. 3514-3520.

Shultz, L.D., Schweitzer, P.A., Christianson, S.W., Gott, B., Schweitzer, I.B., Tennent, B., McKenna, S., Mobraaten, L., Rajan, T.V., Greiner, D.L., et al. (1995). Multiple defects in innate and adaptive immunologic function in NOD/LtSz-scid mice. Journal of Immunology, Vol.154, No.1, pp. 180-191.

Siliciano, J.D., Lai, J., Callender, M., Pitt, E., Zhang, H., Margolick, J.B., Gallant, J.E., Cofrancesco, J., Jr., Moore, R.D., Gange, S.J., et al. (2007). Stability of the latent reservoir for HIV-1 in patients receiving valproic acid. Journal of Infectious Diseases, Vol.195, No.6, pp. 833-836.

Singer, R., Derby, N., Rodriguez, A., Kizima, L., Kenney, J., Aravantinou, M., Chudolij, A., Gettie, A., Blanchard, J., Lifson, J.D., et al. (2011). The nonnucleoside reverse transcriptase inhibitor MIV-150 in carrageenan gel prevents rectal transmission of simian/human immunodeficiency virus infection in macaques. Journal of Virology, Vol.85, No.11, pp. 5504-5512.

Smith, M.S., Foresman, L., Lopez, G.J., Tsay, J., Wodarz, D., Lifson, J.D., Page, A., Wang, C., Li, Z., Adany, I., et al. (2000a). Lasting effects of transient postinoculation tenofovir 
[9-R-(2-Phosphonomethoxypropyl)adenine] treatment on SHIV(KU2) infection of rhesus macaques. Virology, Vol.277, No.2, pp. 306-315.

Smith, S.M., Baskin, G.B., and Marx, P.A. (2000b). Estrogen protects against vaginal transmission of simian immunodeficiency virus. Journal of Infectious Diseases, Vol.182, No.3, pp. 708-715.

Song, E., Zhu, P., Lee, S.K., Chowdhury, D., Kussman, S., Dykxhoorn, D.M., Feng, Y., Palliser, D., Weiner, D.B., Shankar, P., et al. (2005). Antibody mediated in vivo delivery of small interfering RNAs via cell-surface receptors. Nature Biotechnology, Vol.23, No.6, pp. 709-717.

Stoddart, C.A., Joshi, P., Sloan, B., Bare, J.C., Smith, P.C., Allaway, G.P., Wild, C.T., and Martin, D.E. (2007). Potent activity of the HIV-1 maturation inhibitor bevirimat in SCID-hu Thy/Liv mice. PLoS One, Vol.2, No.11, p. e1251.

Stolte-Leeb, N., Loddo, R., Antimisiaris, S., Schultheiss, T., Sauermann, U., Franz, M., Mourtas, S., Parsy, C., Storer, R., La Colla, P., et al. (2011). Topical non-nucleoside reverse transcriptase inhibitor MC 1220 partially prevents vaginal RT-SHIV infection of macaques. AIDS Research and Human Retroviruses, Vol.27, No.9, pp. 933-43.

Stremlau, M., Owens, C.M., Perron, M.J., Kiessling, M., Autissier, P., and Sodroski, J. (2004). The cytoplasmic body component TRIM5alpha restricts HIV-1 infection in Old World monkeys. Nature, Vol.427, No.6977, pp. 848-853.

Subbarao, S., Ramos, A., Kim, C., Adams, D., Monsour, M., Butera, S., Folks, T., and Otten, R.A. (2007). Direct stringency comparison of two macaque models (single-high vs. repeatlow) for mucosal HIV transmission using an identical anti-HIV chemoprophylaxis intervention. Journal of Medical Primatology, Vol.36, No.4-5, pp. 238-243.

Sun, Z., Denton, P.W., Estes, J.D., Othieno, F.A., Wei, B.L., Wege, A.K., Melkus, M.W., Padgett-Thomas, A., Zupancic, M., Haase, A.T., et al. (2007). Intrarectal transmission, systemic infection, and CD4+ T cell depletion in humanized mice infected with HIV-1. Journal of Experimental Medicine, Vol.204, No.4, pp. 705-714.

Tabet, S.R., Surawicz, C., Horton, S., Paradise, M., Coletti, A.S., Gross, M., Fleming, T.R., Buchbinder, S., Haggitt, R.C., Levine, H., et al. (1999). Safety and toxicity of nonoxynol-9 gel as a rectal microbicide. Sexually Transmitted Diseases, Vol.26, No.10, pp. 564-571.

Tagat, J.R., McCombie, S.W., Nazareno, D., Labroli, M.A., Xiao, Y., Steensma, R.W., Strizki, J.M., Baroudy, B.M., Cox, K., Lachowicz, J., et al. (2004). Piperazine-based CCR5 antagonists as HIV-1 inhibitors. IV. Discovery of 1-[(4,6-dimethyl-5pyrimidinyl)carbonyl]- 4-[4-[2-methoxy-1(R)-4-(trifluoromethyl)phenyl]ethyl-3(S)methyl-1-piperaz inyl]- 4-methylpiperidine (Sch-417690/Sch-D), a potent, highly selective, and orally bioavailable CCR5 antagonist. Journal of Medicinal Chemistry, Vol.47, No.10, pp. 2405-2408.

Tevi-Benissan, C., Makuva, M., Morelli, A., Georges-Courbot, M.C., Matta, M., Georges, A., and Belec, L. (2000). Protection of cynomolgus macaque against cervicovaginal transmission of SIVmac251 by the spermicide benzalkonium chloride. Journal of Acquired Immune Deficiency Syndromes, Vol.24, No.2, pp. 147-153.

Traggiai, E., Chicha, L., Mazzucchelli, L., Bronz, L., Piffaretti, J.C., Lanzavecchia, A., and Manz, M.G. (2004). Development of a human adaptive immune system in cord blood cell-transplanted mice. Science, Vol.304, No.5667, pp. 104-107.

Tsai, C.C., Emau, P., Follis, K.E., Beck, T.W., Benveniste, R.E., Bischofberger, N., Lifson, J.D., and Morton, W.R. (1998). Effectiveness of postinoculation (R)-9-(2- 
phosphonylmethoxypropyl) adenine treatment for prevention of persistent simian immunodeficiency virus SIVmne infection depends critically on timing of initiation and duration of treatment. Journal of Virology, Vol.72, No.5, pp. 4265-4273.

Tsai, C.C., Emau, P., Jiang, Y., Agy, M.B., Shattock, R.J., Schmidt, A., Morton, W.R., Gustafson, K.R., and Boyd, M.R. (2004). Cyanovirin-N inhibits AIDS virus infections in vaginal transmission models. AIDS Research and Human Retroviruses, Vol.20, No.1, pp. 11-18.

Tsai, C.C., Emau, P., Jiang, Y., Tian, B., Morton, W.R., Gustafson, K.R., and Boyd, M.R. (2003). Cyanovirin-N gel as a topical microbicide prevents rectal transmission of SHIV89.6P in macaques. AIDS Research and Human Retroviruses, Vol.19, No.7, pp. 535-541.

Tsai, C.C., Follis, K.E., Sabo, A., Beck, T.W., Grant, R.F., Bischofberger, N., Benveniste, R.E., and Black, R. (1995). Prevention of SIV infection in macaques by (R)-9-(2phosphonylmethoxypropyl)adenine. Science, Vol.270, No.5239, pp. 1197-1199.

Tuerk, C., and Gold, L. (1990). Systematic evolution of ligands by exponential enrichment: RNA ligands to bacteriophage T4 DNA polymerase. Science, Vol.249, No.4968, pp. 505-510.

Turville, S.G., Aravantinou, M., Miller, T., Kenney, J., Teitelbaum, A., Hu, L., Chudolij, A., Zydowsky, T.M., Piatak, M., Jr., Bess, J.W., Jr., et al. (2008). Efficacy of Carraguardbased microbicides in vivo despite variable in vitro activity. PLoS One, Vol.3, No.9, pp. e3162.

Uberla, K., Stahl-Hennig, C., Bottiger, D., Matz-Rensing, K., Kaup, F.J., Li, J., Haseltine, W.A., Fleckenstein, B., Hunsmann, G., Oberg, B., et al. (1995). Animal model for the therapy of acquired immunodeficiency syndrome with reverse transcriptase inhibitors. Proceedings of the National Academy of Sciences USA, Vol.92, No.18, pp. 8210-8214.

Valentine, L.E., and Watkins, D.I. (2008). Relevance of studying T cell responses in SIVinfected rhesus macaques. Trends in Microbiology, Vol.16, No.12, pp. 605-611.

Van Heuverswyn, F., Li, Y., Neel, C., Bailes, E., Keele, B.F., Liu, W., Loul, S., Butel, C., Liegeois, F., Bienvenue, Y., et al. (2006). Human immunodeficiency viruses: SIV infection in wild gorillas. Nature, Vol.444, No.7116, p. 164.

Van Rompay, K.K. (2010). Evaluation of antiretrovirals in animal models of HIV infection. Antiviral Research, Vol.85, No.1, pp. 159-175.

Van Rompay, K.K., Brignolo, L.L., Meyer, D.J., Jerome, C., Tarara, R., Spinner, A., Hamilton, M., Hirst, L.L., Bennett, D.R., Canfield, D.R., et al. (2004). Biological effects of shortterm or prolonged administration of 9-[2-(phosphonomethoxy)propyl]adenine (tenofovir) to newborn and infant rhesus macaques. Antimicrobial Agents and Chemotherapy, Vol.48, No.5, pp. 1469-1487.

Van Rompay, K.K., Hamilton, M., Kearney, B., and Bischofberger, N. (2005). Pharmacokinetics of tenofovir in breast milk of lactating rhesus macaques. Antimicrobial Agents and Chemotherapy, Vol.49, No.5, pp. 2093-2094.

Van Rompay, K.K., Johnson, J.A., Blackwood, E.J., Singh, R.P., Lipscomb, J., Matthews, T.B., Marthas, M.L., Pedersen, N.C., Bischofberger, N., Heneine, W., et al. (2007). Sequential emergence and clinical implications of viral mutants with K70E and K65R mutation in reverse transcriptase during prolonged tenofovir monotherapy in rhesus macaques with chronic RT-SHIV infection. Retrovirology, Vol.4, p. 25.

Van Rompay, K.K., Kearney, B.P., Sexton, J.J., Colon, R., Lawson, J.R., Blackwood, E.J., Lee, W.A., Bischofberger, N., and Marthas, M.L. (2006). Evaluation of oral tenofovir 
disoproxil fumarate and topical tenofovir GS-7340 to protect infant macaques against repeated oral challenges with virulent simian immunodeficiency virus. Journal of Acquired Immune Deficiency Syndromes, Vol.43, No.1, pp. 6-14.

Van Rompay, K.K., Matthews, T.B., Higgins, J., Canfield, D.R., Tarara, R.P., Wainberg, M.A., Schinazi, R.F., Pedersen, N.C., and North, T.W. (2002a). Virulence and reduced fitness of simian immunodeficiency virus with the M184V mutation in reverse transcriptase. Journal of Virology, Vol.76, No.12, pp. 6083-6092.

Van Rompay, K.K., McChesney, M.B., Aguirre, N.L., Schmidt, K.A., Bischofberger, N., and Marthas, M.L. (2001). Two low doses of tenofovir protect newborn macaques against oral simian immunodeficiency virus infection. Journal of Infectious Diseases, Vol.184, No.4, pp. 429-438.

Van Rompay, K.K., Schmidt, K.A., Lawson, J.R., Singh, R., Bischofberger, N., and Marthas, M.L. (2002b). Topical administration of low-dose tenofovir disoproxil fumarate to protect infant macaques against multiple oral exposures of low doses of simian immunodeficiency virus. Journal of Infectious Diseases, Vol.186, No.10, pp. 1508-1513.

Veazey, R.S., Ketas, T.A., Klasse, P.J., Davison, D.K., Singletary, M., Green, L.C., Greenberg, M.L., and Moore, J.P. (2008). Tropism-independent protection of macaques against vaginal transmission of three SHIVs by the HIV-1 fusion inhibitor T-1249. Proceedings of the National Academy of Sciences USA, Vol.105, No.30, pp. 10531-10536.

Veazey, R.S., Ketas, T.J., Dufour, J., Moroney-Rasmussen, T., Green, L.C., Klasse, P.J., and Moore, J.P. (2010). Protection of rhesus macaques from vaginal infection by vaginally delivered maraviroc, an inhibitor of HIV-1 entry via the CCR5 coreceptor. Journal of Infectious Diseases, Vol.202, No.5, pp. 739-744.

Veazey, R.S., Klasse, P.J., Ketas, T.J., Reeves, J.D., Piatak, M., Jr., Kunstman, K., Kuhmann, S.E., Marx, P.A., Lifson, J.D., Dufour, J., et al. (2003a). Use of a small molecule CCR5 inhibitor in macaques to treat simian immunodeficiency virus infection or prevent simian-human immunodeficiency virus infection. Journal of Experimental Medicine, Vol.198, No.10, pp. 1551-1562.

Veazey, R.S., Klasse, P.J., Schader, S.M., Hu, Q., Ketas, T.J., Lu, M., Marx, P.A., Dufour, J., Colonno, R.J., Shattock, R.J., et al. (2005a). Protection of macaques from vaginal SHIV challenge by vaginally delivered inhibitors of virus-cell fusion. Nature, Vol.438, No.7064, pp. 99-102.

Veazey, R.S., Ling, B., Green, L.C., Ribka, E.P., Lifson, J.D., Piatak, M., Jr., Lederman, M.M., Mosier, D., Offord, R., and Hartley, O. (2009). Topically applied recombinant chemokine analogues fully protect macaques from vaginal simian-human immunodeficiency virus challenge. Journal of Infectious Diseases, Vol.199, No.10, pp. 1525-1527.

Veazey, R.S., Shattock, R.J., Pope, M., Kirijan, J.C., Jones, J., Hu, Q., Ketas, T., Marx, P.A., Klasse, P.J., Burton, D.R., et al. (2003b). Prevention of virus transmission to macaque monkeys by a vaginally applied monoclonal antibody to HIV-1 gp120. Nature Medicine, Vol.9, No.3, pp. 343-346.

Veazey, R.S., Springer, M.S., Marx, P.A., Dufour, J., Klasse, P.J., and Moore, J.P. (2005b). Protection of macaques from vaginal SHIV challenge by an orally delivered CCR5 inhibitor. Nature Medicine, Vol.11, No.12, pp. 1293-1294.

Vourvahis, M., Tappouni, H.L., Patterson, K.B., Chen, Y.C., Rezk, N.L., Fiscus, S.A., Kearney, B.P., Rooney, J.F., Hui, J., Cohen, M.S., et al. (2008). The pharmacokinetics 
and viral activity of tenofovir in the male genital tract. Journal of Acquired Immune Deficiency Syndromes, Vol.47, No.3, pp. 329-333.

Watanabe, S., Terashima, K., Ohta, S., Horibata, S., Yajima, M., Shiozawa, Y., Dewan, M.Z., Yu, Z., Ito, M., Morio, T., et al. (2007). Hematopoietic stem cell-engrafted NOD/SCID/IL2Rgamma null mice develop human lymphoid systems and induce long-lasting HIV-1 infection with specific humoral immune responses. Blood, Vol.109, No.1, pp. 212-218.

Watson, A., McClure, J., Ranchalis, J., Scheibel, M., Schmidt, A., Kennedy, B., Morton, W.R., Haigwood, N.L., and Hu, S.L. (1997). Early postinfection antiviral treatment reduces viral load and prevents CD4+ cell decline in HIV type 2-infected macaques. AIDS Research and Human Retroviruses, Vol.13, No.16, pp. 1375-1381.

Wheeler, L.A., Trifonova, R., Vrbanac, V., Basar, E., McKernan, S., Xu, Z., Seung, E., Deruaz, M., Dudek, T., Einarsson, J.I., et al. (2011). Inhibition of HIV transmission in human cervicovaginal explants and humanized mice using CD4 aptamer-siRNA chimeras. Journal of Clinical Investigation, Vol.121, No.6, pp. 2401-2412.

Wilkinson, D., Tholandi, M., Ramjee, G., and Rutherford, G.W. (2002). Nonoxynol-9 spermicide for prevention of vaginally acquired HIV and other sexually transmitted infections: systematic review and meta-analysis of randomised controlled trials including more than 5000 women. The Lancet, Vol.2, No.10, pp. 613-617.

Winters, M.A., Van Rompay, K.K., Kashuba, A.D., Shulman, N.S., and Holodniy, M. (2010). Maternal-fetal pharmacokinetics and dynamics of a single intrapartum dose of maraviroc in rhesus macaques. Antimicrobial Agents and Chemotherapy, Vol.54, No.10, pp. 4059-4063.

Wyand, M.S., Manson, K.H., Miller, C.J., and Neurath, A.R. (1999). Effect of 3hydroxyphthaloyl-beta-lactoglobulin on vaginal transmission of simian immunodeficiency virus in rhesus monkeys. Antimicrobial Agents and Chemotherapy, Vol.43, No.4, pp. 978-980.

Yuan, X., Naguib, S., and Wu, Z. (2011). Recent advances of siRNA delivery by nanoparticles. Expert Opinion on Drug Delivery, Vol.8, No.4, pp. 521-536.

Zamore, P.D., Tuschl, T., Sharp, P.A., and Bartel, D.P. (2000). RNAi: double-stranded RNA directs the ATP-dependent cleavage of mRNA at 21 to 23 nucleotide intervals. Cell, Vol.101, No.1, pp. 25-33.

Zhou, J., Chen, C.H., and Aiken, C. (2004). The sequence of the CA-SP1 junction accounts for the differential sensitivity of HIV-1 and SIV to the small molecule maturation inhibitor 3-O-\{3',3'-dimethylsuccinyl\}-betulinic acid. Retrovirology, Vol.1, p. 15.

Zink, M.C., Brice, A.K., Kelly, K.M., Queen, S.E., Gama, L., Li, M., Adams, R.J., Bartizal, C., Varrone, J., Rabi, S.A., et al. (2010). Simian immunodeficiency virus-infected macaques treated with highly active antiretroviral therapy have reduced central nervous system viral replication and inflammation but persistence of viral DNA. Journal of Infectious Diseases, Vol.202, No.1, pp. 161-170. 


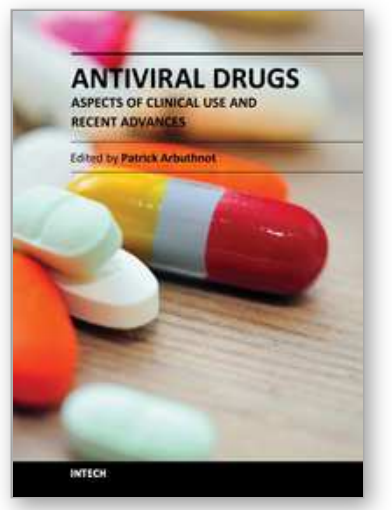

\author{
Antiviral Drugs - Aspects of Clinical Use and Recent Advances \\ Edited by Dr. Patrick Arbuthnot
}

ISBN 978-953-51-0256-4

Hard cover, 194 pages

Publisher InTech

Published online 14, March, 2012

Published in print edition March, 2012

The articles that appear in Antiviral Drugs - Aspects of Clinical Use and Recent Advances cover several topics that reflect the varied mechanisms of viral disease pathogenesis and treatment. Clinical management and new developments in the treatment of virus-related diseases are the two main sections of the book. The first part reviews the treatment of hepatitis $C$ virus infection, the management of virus-related acute retinal necrosis, the use of leflunomide therapy in renal transplant patients, and mathematical modeling of HIV-1 treatment responses. Basic research topics are dealt with in the second half of the book. New developments in the treatment of the influenza virus, the use of animal models for HIV-1 drug development, the use of single chain camelid antibodies against negative strand RNA viruses, countering norovirus infection, and the use of plant extracts to treat herpes simplex virus infection are described. The content of the book is not intended to be comprehensive, but aims to provide the reader with insights into selected aspects of established and new viral therapies.

\title{
How to reference
}

In order to correctly reference this scholarly work, feel free to copy and paste the following:

Zandrea Ambrose (2012). Use of Animal Models for Anti-HIV Drug Development, Antiviral Drugs - Aspects of Clinical Use and Recent Advances, Dr. Patrick Arbuthnot (Ed.), ISBN: 978-953-51-0256-4, InTech, Available from: http://www.intechopen.com/books/antiviral-drugs-aspects-of-clinical-use-and-recent-advances/use-ofanimal-models-for-anti-hiv-drug-development

\section{INTECH}

open science | open minds

\section{InTech Europe}

University Campus STeP Ri

Slavka Krautzeka 83/A

51000 Rijeka, Croatia

Phone: +385 (51) 770447

Fax: +385 (51) 686166

www.intechopen.com

\section{InTech China}

Unit 405, Office Block, Hotel Equatorial Shanghai

No.65, Yan An Road (West), Shanghai, 200040, China

中国上海市延安西路65号上海国际贵都大饭店办公楼 405 单元

Phone: +86-21-62489820

Fax: $+86-21-62489821$ 
(C) 2012 The Author(s). Licensee IntechOpen. This is an open access article distributed under the terms of the Creative Commons Attribution 3.0 License, which permits unrestricted use, distribution, and reproduction in any medium, provided the original work is properly cited. 